\title{
Marka Maskotlarında Antropomorfizm Kullanımına Yönelik Göstergebilimsel Bir Analiz: Arçelik Markası Robot Çelik Vakası1
}

\author{
Burcu DELIKKAN² ve Gül ŞENER ${ }^{3}$
}

\section{$\ddot{O} z$}

Bugünün pazarlama anlayışında, markaların sundukları fayda kadar sahip oldukları kimlik ve tüketicileriyle kurdukları ilişki üzerinden de değer kazandığı görüşü önemli yer tutmaktadır. Bununla birlikte, markalı ürün ve hizmetlere insani özellikler atfedilmesi pratiği giderek artmaktadır. Marka maskotları, antropomorfizm olarak tanımlanan bu pratiğin en yaygın örnekleridir. Bu çalışmanın amacı, marka maskotlarında antropomorfizm kullanımını Arçelik markasının Çelik robotu vakası üzerinden göstergebilimsel açıdan değerlendirmek ve Çelik'in sahip olduğu antropomorfik özelliklerin Arçelik marka kimliğine yönelik inşa ettiği anlamları irdelemektir. Çalışma kapsamında, Çelik robotunun insanlaştırma aşamalarını (çocukluk-genç yetişkinlik-olgunluk) temsil ettiği düşünülen dört Arçelik televizyon reklamı amaçlı örnekleme yöntemiyle belirlenmiş ve göstergebilimsel analiz yöntemiyle incelenmiştir. Analiz sonucunda; antropomorfik marka maskotu Çelik’in sahip olduğu insani özelliklerin (örn. akıllı, yaratıcı, dünya vatandaşı) Arçelik’in yenilenen marka kimliğinin temel özellikleriyle (örn. teknolojik, yenilikçi, global yerlilik) örtüştüğü bulgulanmıştır. Bu durum; marka adının, logosunun, maskotun ve markalı ürün/hizmetin tam bir örtüşme içinde bulunduğu ve birbirinin yerine geçer biçimde tekleştiği "eşleştirme" maskot stratejisinin işlerlikte olduğunu göstermektedir.

Anabtar Kelimeler: Marka maskotu, Antropomorfizm, Marka kimliği, Göstergebilim

\section{A Semiotical Analysis of the Use of Anthropomorphism in Brand Mascots: The Case of Arçelik's Çelik the Robot}

\begin{abstract}
In today's marketing, the idea that brands gain value not just through their benefit but the identity they project and their relationship with consumers is of great importance. In parallel with this marketing approach, to infuse humanlike qualities to products and services is gaining momentum. Brand mascots are the most widespread examples of this practice called anthropomorphism. The objective of this study is to examine the use of anthropomorphism in brand mascots through Arçelik's Çelik the Robot case, to analyze the meanings that are conveyed by the anthropomorphic qualities of Çelik the Robot and their association with Arçelik's brand identity from a semiotic perspective. Within the confines of this study, four Arçelik television commercials that represent different life stages of Çelik the Robot (childhood-young adulthood-maturity) were selected by purposive sampling method and were subjected to semiotic analysis. The results reveal that human like features that the brand mascot Çelik possessed (e.g. smart, creative, world citizen) match with the main determinants of Arçelik's renewed brand identity (e.g. technological, innovativeness, global locality). This situation shows that the "matching" mascot strategy, in which the brand name, logo, mascot and branded product/service are in complete overlap and are interchangeably unified..
\end{abstract}

Key Words: Brand mascot, Anthropomorphism, Brand identity, Semiotics

\section{Atıf İçin / Please Cite As:}

Delikan, B. ve Şener, G. (2020). Marka maskotlarında antropomorfizm kullanımına yönelik göstergebilimsel bir analiz: Arçelik markası robot çelik vakası. Manas Sosyal Araştırmalar Dergisi, 9(3), 1836-1854.

Geliş Tarihi / Received Date: 29.08.2019

Kabul Tarihi / Accepted Date: 17.04.2020

\footnotetext{
${ }^{1}$ Bu çalışma, Bahçeşehir Üniversitesi Sosyal Bilimler Enstitüsü Reklamcllık ve Marka İletişimi Yönetimi Programı’nda Dr. Öğr. Üyesi Gül Şener danışmanlığında Burcu Delikan tarafından "Marka Maskotlarında Antropomorfizm Kullanımının Göstergebilimsel Analizi: Arçelik-Çelik Örneği” ismiyle 2019 yllında tamamlanan yüksek lisans tezinden üretilmiştir.

${ }^{2}$ Yüksek Lisans Öğrencisi (Mezun) - Türkiye - Bahçeşehir Üniversitesi, Sosyal Bilimler Enstitüsü, burcudelikan@gmail.com ORCID: 0000-0001-7800-1394

${ }_{3}^{3}$ Dr. Öğr. Üyesi - Türkiye - Bahçeşehir Üniversitesi, İletişim Fakültesi, gul.sener@comm.bau.edu.tr ORCID: 0000-0002-8063-7233
} 


\section{Giriş}

Guthrie’ye (1997, s. 53) göre "gökyüzündeki bulutları, budaklı dalları ve diğer insan dışı biçimleri insan yüzlerine benzetme dürtümüz veya gece vakti kaynağını teşhis edemediğimiz sesleri insan sesi olarak değerlendirmemiz evrensel bir olgudur". Bu düşüncenin kökenlerini felsefeci David Hume'da sürmek mümkündür. Hume $(1875$, s. 317) insanların her varllğı kendisi gibi algılama ve bu insangibiliği her türlü nesneye aktarma eğilimine sahip olduğunu savunmuştur. Betimlenen bu insan algis1 antropomorfik düşünce olarak tanımlanmaktadır. Bu anlamda; "insan dışındaki varlıkların hayal edilen ya da var olan davranışlarına insan benzeri özellikler, motivasyonlar, niyetler ve duygular atfetmek antropomorfizmin temelini oluşturmaktadır" (Epley, Waytz ve Cacioppo, 2007, s. 864-865). Hal böyleyken; günlük hayat içerisinde hayvanların, doğal olayların ve doğaüstü olguların, mekanik ve teknolojik araçların insanlaştırıldığı durumlarla sıklıkla karşılaşıyoruz.

Antropomorfizm aynı zamanda bir marka stratejisi olarak da uygulama alanına sahip bir olgudur. Bugünün dünyasında pazarlamacılar; ürün/hizmet, marka veya şirketlere insani özellikler kazandırarak onları tüketiciler için birer ilişki partnerine dönüştürmeye çalışmaktadır (Fournier, 1998). Castelli, Happe, Frith ve Frith'in (2000) yaptıkları araştırmanın sonuçları, insanların cansız nesnelere dair antropomorfik düşünceleri sırasında aktive olan beyindeki sinir alanlarıyla insanlara dair belirli bir yargiya varırken aktive olanların aynı olduğunu ortaya koymaktadır. Diğer bir deyişle, insanlar antropomorfik cansız varlıklarla (örn. markalı ürün/hizmetler) ilgili düşünce geliștirirken onları tıpkı insan gibi değerlendirmektedir. Tüketiciler belirli ürünlerin insan benzeri özelliklere sahip olduğuna inandığında bu ürünleri daha fazla beğenmekte (Aggarwal ve McGill, 2012) ve söz konusu ürünleri değiştirmekten kaçınmaktadır (Chandler ve Schwarz, 2010). Bu tüketici gerçeğinden yola çıkan pazarlamacılar; antropomorfizm yaklaşımını çoğunlukla marka karakterleri, maskotlar ve marka sözcüleri üzerinden gerçekleştirmektedir. Çünkü; tüketiciler marka karakterlerini özdeşlik kurabilecekleri, kişilik özellikleriyle kendilerini bağdaştırabilecekleri ve hikayelerinde kendilerini bulabilecekleri figürler olarak algilamaktadır (Khogeer, 2013, s. 51).

Marka kimliğinin maskotlar gibi cansız nesnelerin insanlaştırllması üzerinden belirli özelliklerle bağdaştırılmasi; rekabetten ayrışmanın ve güçlü bir marka değeri yaratmanın yollarından biri olarak ortaya konmaktadır. Tüketiciler hiç yadırgamadan belirli kişilik özelliklerini markalara yüklemekte (Aaker, 2016), markaları birer karakter olarak algılamakta (Levy, 1985; Plummer, 2000) ve yeri geldiğinde markanın bakıș açısını kendi bakış açısıymışcasına kabul etmektedir (Blackston, 1993). Buradan hareketle, antropomorfizmin markalama ve marka maskot stratejilerinde yaygın biçimde kullanılması şaşırtıcı değildir.

Antropomorfizm kavramının ana kullanım alanlarından biri olan marka maskotlarına dair literatüre bakıldığında, maskotların antropomorfizm ve marka kimliğinin kesişiminde değerlendirildiğine şahit oluyoruz. Antropomorfizmin cansız varlıklara duygusal, davranışsal, zihinsel ve kişiliğe dair insani özellikler atfedilmesi prensibine dayandı̆̆ı düşüncesinden hareketle; marka maskotları da markanın sahiplenmek istediği bu insani özelliklerin taşıyıcıları, yani marka kimliğini temsil eden figürler olarak kabul edilmektedir.

Temsiliyet dediğimizde göstergebilimin alanına da adım atmış oluyoruz. Hali hazırdaki çalışmanın konusu olan marka maskotlarında antropomorfizm kullanımını, "kendisinden başka bir şeye gönderme yapan ve insanların duyularıla kavrayabileceği fiziksel bir şey" (Fiske, 2013, s. 123) olarak tanımlanan göstergelerden bağımsız incelemek elbette ki imkansızdır. Dolayısıyla bu çalışma çerçevesinde, marka kimliğinin ve antropomorfik yaklaşımın birer göstergesi olarak ele alınan marka maskotlarının insani özellikleri ve bu özellikler üzerinden inşa edilen anlamlar göstergebilimsel teoriler bağlamında incelenmiştir.

Marka maskotlarına yönelik geçmiş literatüre bakıldığında; marka farkındalı̆̆ı, marka beğenisi ve hatırlanırlığı, marka imajı ile ilişkisinin nicel ve nitel yöntemlerle araştırıldığ1 görülmektedir. Antropomorfizm ise markalamanın yanı sıra tüketici davranışı çerçevesinde ele alınmaktadır. Markalara yönelik göstergebilimsel araştırmalarda marka kimlik stratejilerinin kendine yeterince yer bulamadığ1 düşüncesi, alanda bu yönde bir boşluğa da işaret etmektedir (Oswald, 2015). Göstergebilimsel teoriler çerçevesinde marka kimliği konusunda yeterince bilgi üretilmemesi, bu alanda yapılacak çalışmaların da önemini artırmaktadır (Lencastre ve Corte-Real, 2013). 
Her ne kadar tüketicilerin ürünlere insan benzeri özellikler yüklemesi (Belk, 1988) literatürde uzun süredir tartışlan bir konu olsa da marka antropomorfizmi ve bunun ürün/hizmetle alakalı (Puzakova, Kwak ve Rocereto, 2013) ve tüketiciyle alakalı (Kim ve Kramer, 2015; MacInnis ve Folkes, 2017) çlktılara etkisi ancak yakın zamanda mercek altına alınmıştır. Bu çalışma; Arçelik markasının Çelik robotu üzerinden marka maskotlarında antropomorfizm kullanımının marka kimliğine yönelik ne tür anlamlar ürettiğini göstergebilimsel analiz yöntemiyle sorgularken alandaki bilgi açığına da katkı sağlamayı amaçlamaktadır. Ek olarak, analizin Çelik maskotu üzerinden yapılması, antropomorfizm gibi soyut bir kavramın somut bir örnek üzerinden değerlendirilmesine de olanak tanıyacaktır. Bu kapsamda, söz konusu çalışmada aşağıdaki araştırma sorularına cevap aranmaktadır:

Araştrma Sorusuı: Maskotlarda antropomorfizm kullanımı, marka kimliğine yönelik anlamları hangi göstergebilimsel ilişkiler üzerinden inşa etmektedir?

Arasțtrma Sorusu2: Marka maskotu olarak Çelik'in sahip olduğu antropomorfik özellikler hangi düz ve yananlamları üretmektedir?

Araştrrma Sorusuz: Marka maskotu olarak Çelik'in sahip olduğu antropomorfik özellikler Arçelik'in marka kimliğine yönelik ne tür anlamlar barındırmaktadır?

\section{Literatür Taraması}

\section{Antropomorfizm Kavramı}

Antropomorfizm, Yunanca "anthros" yani insan ve "morphos" form kelimelerinin birleşiminden oluşmaktadır. Antropomorfizm sözlük anlamıyla "soyut objelerin ya da hayvanların kişileştirilmesi, insani özelliklerinin insan olmayan varlıklara ve durumlara yüklenmesi" (Merriam-Webster) biçiminde tanımlanmaktadır. Spada (1997, s. 37) söz konusu kavramı "insan görünüşünün ve özelliklerinin, başta tanrilar olmak üzere, canlı veya cansız herhangi bir şeye aktarılması" olarak nitelemiştir. Antropomorfizmin birçok farklı biçimde tanımlandığı görülmektedir. Bir kısım teorisyen antropomorfizmin insan ya da insan benzeri özelliklerin hayvanlara yüklenmesi olduğunu savunurken (Asquith, 1984; Brown, 2010; Daston ve Mitman, 2005), diğerleri bu özelliklerin nesnelere atfedilmesi anlamını taşıdığını vurgulamıştır (Kassarjian, 1978). Bazıları ise antropomorfizmi daha genel bir çerçeveye oturtarak insan özelliklerinin insan olmayan varlıklara yüklenmesi olarak tarif etmiştir (Kiesler, 2006; Schiffman ve Kanuk, 2009).

Antropomorfizmin kavramsal sınırlarını çizmeye çalışan birçok teorisyen kavramın diğer kavram ve olgularla olan ilişkisini de incelemiş̧ir. Literatürde antropomorfizmi anlamaya yardımcı olduğu vurgulanan kavramlar arasında kişileştirme (Brown, 2011; Danesi, 2004; Khogeer, 2013) ve insanlaştırma (Portal, Abratt ve Bendixen, 2018; Waytz, Epley ve Cacioppo, 2010) sayllabilir. Oxford Dictionary'e göre kişileştirme, insan doğasının ya da karakteristik özelliklerinin insan olmayan şeylere aktarılması ya da soyut bir varlığın insan biçiminde temsil edilmesidir. Kişileştirmenin cansız nesnelere duygusallık, öz farkındalık, kuruntu, vb. insani özellikler atfetmek anlamına geldiği söylenebilir (Brown, 2011, s. 3). Bu durum; bireylerin cansız varlıklara yönelik birçok farklı deneyimini insan motivasyonlanı, özellikleri ve davranışları bağlamında çözümlemeye ve anlamaya imkân vermektedir (Lakoff ve Johnson, 2008, s. 35). McDonald's markasının maskotu Ronald McDonald ya da Malboro markasının Marlboro Adam'1 marka karakterlerindeki kişileştirme kullanımına verilebilecek örneklerdendir.

MacInnis ve Folkes (2017) markaları insanlaştırma yaklaşımını antropomorfizmi de kapsayan bir şemsiye kavram olarak kabul etmektedir. İnsanlaştırma kavramının alt kategorilerini antropomorfizm, benim gibi markalar yaklaşımı (tüketicinin markayı kendisiyle örtüştürmesi), ilişki odaklı yaklaşım (markaları birer ilişki partneri olarak gören bakış) oluşturmaktadır. Bu çerçevede, bireylerin insanlaştırma eğilimi hem insan hem de insan olmayan varlikları kapsarken, antropomorfizm insan olmayan varlık ve olaylarla sinırlıdır (Waytz vd., 2010) ve insanlaştırmanın en uç noktası olarak kabul edilmektedir. Fournier (1998) antropomorfizmin marka iletişiminin bir gerekliliği olarak görülmesini savunmaktadır.

Antropomorfizm 4 farklı biçimde gerçekleşebilir (DiSalvo, Gemperle ve Forlizzi, 2005, s. 4-5):

- Yapısal Antropomorfik Biçim (structural): Yapısal antropomorfik biçim insan vücudunun yapısının ve işleyişinin maddesel anlamda taklit edilmesidir. Görünüm ya da işleyiş olarak insan vücudunu taklit eden şekiller, hacimler, mekanizmalar ya da düzenekler yapısal antropomorfik biçimin kanitlarıdır. 
- Jest Temelli Antropomorfik Biçim (gestural): Bu antropomorfik biçim insanların vücutlar1 üzerinden birbiriyle nasıl iletişim kurduklarının insan davranışlarına odaklanarak taklit edilmesiyle ilgilidir. İnsan davranışlarının unsurları olan hareket ve duruşların herhangi bir anlamı, niyeti ya da yönlendirmeyi ifade eder biçimde kullanılması jest temelli antropomorfik biçime örnek gösterilebilir.

- Karakter Temelli Antropomorfik Biçim (character): Bu biçim daha çok insanların kişilik özelliklerinin, sosyal rollerinin ve herhangi bir bağlam içerisindeki işlevlerinin taklit edilmesiyle ilgilidir. İnsanların kim olduklarını dışa vuran özelliklerin ve alışkanlıkların cansız varlıklara yansıtılması bu biçimin işlerlikte olduğunun kanıtıdır.

- Farkendalik Temelli Antropomorfike Biçim (aware): Bu biçim, insanların düşünme ve sorgulama yetilerinin taklit edilmesi prensibine dayanır. Günümüzdeki robotik ve yapay zekâ uygulamaları farkındalık temelli antropomorfik biçimlere örnek gösterilebilir.

Pazarlama alanında giderek artan antropomorfize etme eğiliminin izlerini; Amazon’un Alexa örneğinde olduğu gibi ürünlere insan isimleri verme uygulamalarında, Apple Siri örneğinde olduğu gibi ürüne bir cinsiyet atfetmede ve bu cinsiyetle uyumlu bir ses ve aksan yaratmada, Michelin Adam örneğindeki gibi insan benzeri fiziksel özelliklerle donatma uygulamalarında sürmek mümkündür (MacInnis ve Folkes, 2017, s. 358). Bu anlamda; Alexa ve Siri örnekleri karakter ve farkındalı temelli antropomorfik biçimleri yansıtırken Michelin Adam'ın yapısal ve jest temelli bir antropomorfik biçime sahip olduğu söylenebilir.

\section{Markalama Süreci ve Antropomorfik Yaklaşımın Boyutları}

Antropomorfik yaklaşımın anlamsal, toplumsal ve kültürel (Dydynski, 2017; Epley ve Waytz, 2010; Guthrie, 1993; Khogeer, 2013; Kim ve McGill, 2013) boyutlanı bulunmaktadır. Guthrie (1993) "insanlar neden antropomorfize etme ihtiyacı hissediyor?" sorusuna cevap ararken üç önemli neden üzerinde durmaktadır. İlk olarak, insanların çevrelerinde olup bitenleri algılarken ve anlamlandırırken bunu kendileri ile ilgili sahip oldukları bilgi üzerinden gerçekleştirmektedir. İkinci olarak, insanlar ilişki ve arkadaşlık konusunda hissettikleri boşluğu ya da eksikliği bertaraf edecek nesne ve varlıklara antropomorfizm yoluyla ulaşmak istemektedir. Üçüncü ve son sebep ise insanların dünyayı daha insana benzer şekilde inşa etme ihtiyacına sahip olmalarıdır (Khogeer, 2013, s. 29). Bu üç sebep, antropomorfik yaklaşıma anlamsal, toplumsal ve kültürel boyutlardan bakılmasını da destekler niteliktedir:

- Anlamsal boyut: Antropomorfik yaklaşımın anlamsal boyutunun temel işlevi; insanları kendileri dışındaki varlıkların motivasyonlarını anlama yönünde teşvik etmesi ve bu varlıkların gelecekte nasıl davranacaklarını tahmin ve kontrol etme noktasında araçsallaşmasıdır (Epley vd., 2007). Marka açısından değerlendirildiğinde ise; tüketiciler antropomorfik markaların çeşitli duygu, düşünce ve bilinçli davranışın yanı sıra aslında bir ruha sahip olduğunu düşünmektedir. Bu sebeple, toplumun parçası olan gerçek bir insanmış gibi yaklaşılması gerektiğine inanmaktadır (Khogeer, 2013, s. 24).

- Toplumsal boyut: Antropomorfik yaklaşımın toplumsal boyutunun altında yatan nedenler arasında bireyin çevresini kontrol etme motivasyonunun yanı sıra yalnızlığı bertaraf etme ve ait olma ihtiyac1 gibi sosyal motivasyonlar sayılmaktadır (Puzakova vd., 2009; Waytz vd., 2010). Epley vd. (2007) sosyal ilişkilerdeki yetersizliğin bireylerin insan olmayan canlıları antropomorfik varlıklar biçiminde algılamasına yol açtığından bahsetmektedir. Bu şekilde; insan olmayan varlıklar insanlarla etkileşime geçen birer sosyal varlığa dönüşmekte ve deneyimlenen yalnızlık duygusunun yarattığ1 boşlukları doldurmaktadır.

- Kültürel boyut: Hofstede’ye (2011) göre kültür insanların çevrelerine yönelik alg1sını şekillendiren temel unsurlardan biridir. $\mathrm{Bu}$ açıdan, günümüz tüketim kültürü bağlaminda antropomorfizm işlevsel bir kavram olarak değerlendirilmektedir (Brown, 2011). Örneğin tüketim kültürü ayıyı, doğası itibariyle vahşi bir hayvan olmasına rağmen bir bebeğin müzik çalarken sarıldığ1 ve en sevdiği peluş oyuncaklardan birine dönüştürmektedir.

Markaların antropomorfize edilmesinin ise belirli aşamalarla gerçekleştiği görülmektedir (Donaldson, 2016). İlk aşamada, ana hedef kitlesinin kişilik özelliklerine odaklanan pazarlamacılar, ikinci aşamada 
markalara tüketicilerininkine benzer kişilik özellikleri yüklemektedir. Son aşamaya gelindiğinde ise, belirli insani özelliklerle donatılan, yani antropomorfize edilen markaların tüketicileri için bir ilişki partnerine dönüşmesi amaçlanmaktadır (Fournier ve Alvarez, 2012).

\section{Marka Maskotlar1 ve Antropomorfizm}

Maskotun anlamına bakıldığında; bir okulu, takımı veya şirketi oluşturan topluluğu simgelemek için kullanılan hayvan, çizgi film karakteri, vb. figürlerin kastedildiği görülmektedir (Çengel, 2006, s. 34). Maskotların pazarlama alanında etkin şekilde kullanılmaya başlaması ise 20. yüzyılın başlarına rastlamaktadır ve günümüze kadar da gelişerek devam etmiştir. Marka maskotları, marka kimliğini temsil eden ve bu kimliğin içerdiği anlamları tüketiciyle buluşturan karakteristik figürler olarak da tanımlanmaktadır (Yadav, Bisoyi ve Chakrabati, 2015, s. 4). Heckman'a (1999) göre maskotlar markanın nefes alan, canlı bir ifadesi, yani markanın somut hali olarak görülmelidir.

Tipkı marka logosu ve sloganı gibi marka maskotu da markanın temel bileşenlerinden biridir. Ürünün veya hizmetin hedef tüketicisine markaya dair görsel ipuçlarını sunan bir araçtır. Marka kimliğini inşa etmeye yarayan karakteristik figürler olarak marka maskotları, markanın kim olduğunu tüketicilere anlatan birer elçi gibi düşünülebilir. Başarılı bir marka maskotu tüketicinin zihninde olumlu bir marka imaj1 yaratmakta, bu durum olumlu marka çağrışımlarını tetiklemekte ve marka ile tüketici arasında olumlu duygulara dayanan bir bağ kurulmasını sağlamaktadır (Mohanty, 2014). Weszka'ya (2011) göre bir marka karakteri yaratmanın nedeni; etkin bir marka kimliği inşa etmek, olumlu çağrışımlar üzerinden markanın tüketiciler nezdinde farkındalığını artırmak ve duygu, düşünce ve kişilik özellikleri gibi insani unsurları kullanarak markaları yaşayan birer varlığa dönüştürmektir. Bu çerçeveden değerlendirildiğinde; marka maskotunun markaya katkı sağlaması için yerine getirmesi gereken bazı kaideler bulunmaktadır. İlk olarak, maskot markanın ruhunu ve şirketin misyon ve hedeflerini bünyesinde barındırmalıdır. Maskot; sembolik renklerle özdeşleşmelidir, olumlu yananlamları bulunan bir ismi olmalıdır ve markanın tüketicilerine belirli mesajlar taşımalıdır (Caufield, 2012, s. 7). Bunlara ek olarak, Lin, Lin ve Ko (1999) maskotun görsel bağlamda etkili olabilmesi için tasarımının tüketicinin tercih ve algılarını yansıtması gerektiğini vurgulamaktadır.

Genel anlamda maskotlar literatürde üç farklı biçimde incelenmektedir (Tosun ve Kalyoncu, 2014, s. 89): (1) Yaşayan canlılar biçimindeki maskotlar, (2) animasyon veya karikatür biçimindeki maskotlar ve (3) yerleşik karakterler biçimindeki maskotlar. Birinci kategorideki maskotlar insan, hayvan veya bitki biçiminde olabilir (Karadağ, 2013, s. 26). Tüm canlılar içinde maskot olarak en çok kullanılan ise hayvanlardır. Animasyon veya karikatür karakterlerinin maskot olarak kullanılması ise cansız nesnelerin tasarlanıp sonra onlara bir karakter kazandırılması sürecini içermektedir. Yerleşik karakterler biçimindeki maskotlar zaten var olan kişiliklerin birer maskot olarak markalar tarafindan sahiplenilmesi prensibine dayanmaktadır. Marka bunu karakterin tüm kullanım haklarını satın alarak gerçekleştirmektedir.

Marka maskotlarn; markayı antropomorfik bir temsil üzerinden görsel olarak ifade eden temel bir unsur, markayı taklit eden ikonik bir gösterge, tüketici ve marka arasında duygusal bir bağ kurulmasını sağlayan bir arac1 olarak nitelenmektedir (Beirao, Lencastre ve Dionisio, 2007, s. 3). Gülver (2017, s. 1) marka maskotunu "tüketicilere ürün, hizmet ve marka hakkında bilgi veren marka sözcüleri" olarak tanımlamaktadır. Phillips ve Lee (2005) markalı ürün, hizmet ya da fikri tanıtmak için kullanılan marka maskotlarının, marka tarafından ve sadece marka için yaratılmasından dolayı literatürde marka sözcüsü olarak tanımlandığını belirtmektedir. Diğer bir deyişle, markalı ürün ya da hizmet kendi adına konuşamayacağı için bu görevi onun yerine üstlenecek bir karaktere ihtiyaç duyulmaktadır. Marka maskotlarının sözcü olarak seçilmesinin nedenlerinden biri de budur (Pairoa ve Arunrangsiwed, 2016, s. 1702). Türkiye'den başarılı örneklere bakıldığında; Turkcell'in maskotu Cell-O sempatik aynı zamanda kendinden emin gözükmeyi, Yapı Kredi’nin Vadaa maskotu bankacıllğın soğuk yüzüne bir sıcaklık kazandırmayı (Küçükerdoğan, 2012), Arçelik markasının Çelik maskotu da globallik ve yerelliği bir arada sunmayı başarmış uygulamalardır (Barutçu ve Adıgüzel, 2015, s. 82-83).

Marka maskotlarının kullanımı hem marka hem tüketici hem de reklam açısından farklı önemlere sahiptir. Maskot markalı bir ürün ya da hizmetle bağdaştırıldığında, artık o markanın sembolü haline gelmektedir. Bu durum da marka hatırlanırlığına katkıda bulunmaktadır. Etkili bir marka maskotu, marka farkındalı̆̆ını artırmakta, tüketici ve marka arasında duygusal bir bağ yaratmakta ve böylece markayı rekabetten ayrıştırmaktadır (Khogeer, 2013, s. 3). Tüm bunların yanı sıra; marka karakteri olarak maskotlar marka imajını olumlu yönde etkilemesi sebebiyle kurumsal kimliğin de gücünü artırmaktadır (Yadav vd., 
2015, s. 2-3). Tüketici açısından değerlendirildiğinde, marka maskotlarının duygusal bir çekicilik sağladığ1 vurgulanmaktadır. İnsanlar bir ürün ya da hizmetin hayranı olmaya mesafeli davranırken marka maskotları gibi insanlaştırılmış nesnelere yakınlık duyması daha kolaydır (Pairoa ve Arunrangsiwed, 2016, s. 1703). Markanın görsel kimlik unsurlarından biri olan iki boyutlu logonun maskot üzerinden üç boyutlu hale dönüşmesi ve maskotun reklamın görsel çekiciliğini artırarak daha dikkat çekici hale getirmesi, marka maskotunun reklam açısından avantajlarını göstermektedir. Reklamda marka maskotu kullanmak, reklamın samimiyet algısını artırmasının yanı sıra izleme deneyimini daha eğlenceli kılmaktadır. Böylece, reklamın potansiyel tüketicilerle arasında bağ kurulması kolaylaşmaktadır. Bu açıdan maskotlar, reklamların daha kişisel, otantik, güvenilir, eğlenceli ve çekici olması yönünde önemli bir katkıya sahiptir (Yadav vd., 2015, s. 4).

\section{Marka Maskotu Stratejileri}

Bir maskotun temel amacı marka kimliğini güçlendirmektir (Brown, 2014). Bu durum, markanın temsilcisi olarak maskotların zaman zaman marka kimliğini bütünüyle içermesiyle sonuçlanmaktadır. Honey Monster ve Jolly Green Giant örneklerinde olduğu gibi şirket maskotun adını alabilmektedir. Bu bağlamda; literatürde markaların benimseyebileceği dört temel maskot stratejisi olduğu belirtilmektedir (Brown, 2010, s. 218-219):

1. Eşleştirme (match): Marka adının, logosunun, maskotun, markalı ürün ve hizmetin tam bir örtüşme içinde olduğu ve buna bağlı olarak hepsinin birbirinin yerine geçer biçimde tekleştiği durumları yansitan stratejidir. Jaguar arabaları, Mr. Clean, Toilet Duck, Penguin kitapları, Red Bull enerji içeceği bu maskot stratejisinin bilinen örnekleridir.

2. Kanşstrma (mix): Marka sözcüsünün ürünü tanıttığı ancak ürünün özelliklerini temsil etmediği durumları yansitan bir strateji olması sebebiyle pazarlamacılar tarafindan tercih edilirliği düşüktür. Geoffrey zürafa/The Toys R Us, Chester çita/Cheetos ve Leo aslan/MGM markanın tanıtımını yapan karakterlerdir.

3. Coğaltma (multiply): Bu strateji pazarlamadaki "daha fazla her zaman daha iyidir" anlayışıyla örtüşmektedir. Bu strateji göre bir marka karakteri iyiyse iki daha iyidir, üç ve daha fazlası ise en iyisidir. MveM'in her biri farklı kişilik özelliklerine sahip altı farklı sözcü şeker karakteri bu stratejinin ilk akla gelen örneklerindendir.

4. Gizem Katma (mystify): Bu stratejide; marka ve maskotu arasındaki bağ gereken düzeyde bir uyumsuzluk noktasında bırakılır. Marka-maskot bağıntısındaki bu fluğluk ya da boşluğun tüketicileri meraklandıracak ve markayla diyaloğa girmesini sağlayacak bir tetikleyici olması amaçlanmaktadır. Örneğin, Fox marka nane şekerlerinin marka maskotu tilki değil kutup ayısıdır. Bu durum neden sorusunu tetiklemektedir.

\section{Yöntem}

Bu çalışmanın amacı, antropomorfizmin marka maskotlarında kullanımının marka kimliğine yönelik oluşturduğu anlamları göstergebilimsel analiz yöntemi ile ortaya koymaktır. Bu çerçevede, Arçelik markasının Çelik marka maskotunun yer aldığı reklamlar göstergebilimsel yöntemlerle analiz edilmiştir.

\section{Evren - Örneklem}

Bu çalışmanın evrenini, marka maskotu olan Çelik'in yer aldığı tüm Arçelik televizyon reklam filmleri oluşturmaktadır. Araştırmanın amacı doğrultusunda analiz edilecek televizyon reklam filmleri amaçl1/yargısal örnekleme yöntemiyle belirlenmiştir. Amaçlı/yargisal örnekleme yöntemi, "ögelerin çalışma örneklerinden rastgele değil, belli özelliklerine dayanarak seçilmesine dayanmaktadır” (Böke, 2011, s. 125). Bu örnekleme yönteminde, "gerekli bilgiyi en iyi şekilde sağlayacak elemanlar örnekleme olarak seçilmektedir" (Özdemir, 2010, s. 95). Bir bakıma, araştırmacının çalışmayı ilgilendiren ana kitleyi en iyi şekilde temsil edeceğini düşündüğü elemanlar örneklemde yer almaktadır. Bu çerçevede, ürün özelliklerine vurgu yapan reklamlar örneklem dışında bırakılmış, marka maskotu Çelik'in yer aldığı ve imaj iletişimi yapan Arçelik reklamları örnekleme dâhil edilmiştir. Nihai örneklem, Çelik'e insan benzeri özelliklerin yüklendiği ve bu özelliklerin Arçelik'in marka kimliğine yönelik anlamlar ürettiği 4 adet reklamı içermektedir. Söz konusu 4 reklam, aynı zamanda antropomorfik bir maskot olarak Çelik'in dönüşümünü de ortaya koyan reklamlar olması sebebiyle örnekleme dahil edilmiştir. Örneklem sırasıyla Arçelik 
markasının "Merhaba Çelik" ve "Arçelik Yeni Logo Lansman" (2002), "Divide\&Cool Teknolojisi” (2008), "Yılın Düğünü" (2012) reklamlarından oluşmaktadır.

\section{Verilerin Analizi}

Çalışma kapsamında; antropomorfik bir marka maskotu olan Çelik'in insani özellikleri marka kimliğinin birer göstergesi olarak değerlendirilmiş ve bu özellikler göstergebilimsel yöntemle incelenmiş, Arçelik'in marka kimliğine yönelik yarattı̆̆1 anlamlar analiz edilmiştir. Reklamları göstergebilimsel açıdan incelemek dediğimizde kastedilen şey; ilk önce reklamda yer alan görsel ve metinsel göstergelerin belirlenmesi, sonra bu göstergelerin bir araya gelerek ne tür kodlar oluşturduğunun analiz edilmesi ve bu kodlar üzerinden hangi anlamlar1 ürettiklerinin incelenmesidir (Bignell, 2002, s. 31). Hali hazırdaki çalışmada göstergebilimsel analiz aşağıda belirtilen üç aşamada gerçekleşmiştir:

a) Antropomorfik marka maskot Celik'in bir gösterge olarak ürettiği anlamlarn analiz̨i: Bu aşamada; göstergebilimsel analiz aracı olarak Peirce'nin görüntüsel gösterge, belirtisel gösterge ve sembol olarak tanımladığı üçlü gösterge kategorizasyonunu temel alan Zakia ve Nadin’in (1987) Yorumcu Matriksi kullanılmışır. Görüntüsel göstergeler (icon), gösterge ve nesne arasındaki ilişkinin benzerlik veya taklit üzerinden işlediği göstergeler olarak tanımlanmaktadır (Chandler, 2002, s. 37). Göstergenin nesnesine bir nedensellik ilişkisiyle bağlı olduğu göstergeler belirtisel gösterge (index) olarak adlandırılmaktadır (Rossolatos, 2017, s. 417-418). Sembol (symbol), göstergenin temsil ettiği nesnesi ile arasındaki ilişkinin bir uzlaşım sonucu kurulduğu göstergeler olarak tanımlanmaktadır (Akerson, 2016, s. 106).

b) Antropomorfik marka maskotu Celik'in reklam olay örgüsü içerisinde bir gösterge olarak ürettï̈i düz, ve yananlamlar: Bu aşamada, göstergebilimsel analiz aracı olarak Barthes'in (2018) düzanlam ve yananlamları incelediği Gösterge Anlamlandırma Modeli kullanılmıştır. Saussure'nin gösterge yaklaşımını anlamın birinci düzeyi olarak tanımlayan Barthes, bu aşamaya "düzanlam" adını vermiştir. Bu düzeyde, "göstergenin göstereni ve gösterileni arasındaki ilişkiye odaklanmış ve göstergenin dışsal gerçeklikteki göndergesiyle ilişkisi...göstergenin ortakduyusal, aşikâr anlamı" (Fiske, 2013, s. 182) üzerinde durmuş̧tur. Barthes'nn ikinci anlamlandırma düzeyi olarak ele aldığ1 yananlam, "göstergenin, kullanıcıların duygu, heyecan ve kültürel değerleriyle buluştuğunda meydana gelen etkileşimi betimlemektedir" (Fiske, 2013, s. 182). İkinci anlamlandırma düzeyinde yer alan bir diğer kategori olan mitik anlam düzeyinde ise "göstergeler kültürün değer sistemi içinde değerlendirilmektedir" (Fiske, 2013, s. 187) ve göstergeler üzerinden inşa edilen toplumsal anlamlar yer almaktadır.

c) Antropomorfik marka maskotu Celik'in ürettiği anlamlarn Arçelik marka kimlï̈i ile bağlantısı: $\mathrm{Bu}$ aşamada analiz aracı olarak, Brown'un (2010) maskot ve marka kimliği stratejileri arasındaki ilişkiyi temel alan Maskot Strateji Modeli (Eşleştirme, Karıştırma, Çoğaltma, Gizem Katma) kullanılmıştır.

\section{Bulgular}

Örnekleme dahil edilen Arçelik reklamlarında; marka maskotu Çelik robot olmasının yanı sıra insan benzeri duygu, davranış ve iletişim yetisine sahip antropomorfik bir varllk olarak resmedilmektedir. Marka maskotu Çelik'in bir gösterge olarak örneklemdeki reklamlarda yansıttı̆̆ı antropomorfizm biçimleri Tablo 1'de sunulmuştur.

Tablo 1. Antropomorfiæm Biçimlerine Göre Marka Maskotu Celik Göstergesi

\begin{tabular}{|c|c|c|c|}
\hline $\begin{array}{c}\text { Yapisal } \\
\text { (Structural) }\end{array}$ & $\begin{array}{l}\text { Jest Temelli } \\
\text { (Gestural) }\end{array}$ & $\begin{array}{c}\text { Karakter Temelli } \\
\text { (Character) }\end{array}$ & $\begin{array}{c}\text { Farkındalık } \\
\text { Temelli (Aware) }\end{array}$ \\
\hline $\begin{array}{l}\text { Çelik robot ve insan birleşimi } \\
\text { bir forma sahiptir. El, kol ve } \\
\text { bacakları ile bir insan } \\
\text { formunu andırırken metal } \\
\text { formu ile de robot olduğu } \\
\text { vurgulanmaktadır. }\end{array}$ & $\begin{array}{l}\text { Çelik'in insana özgü bazı } \\
\text { hareketleri taklit ettiği } \\
\text { görülmektedir. Karşısındaki } \\
\text { kişiye teşekkür ederken elini } \\
\text { göğsüne götürmesi sergilediği } \\
\text { jest temelli antropomorfizm } \\
\text { örneklerinden biridir. }\end{array}$ & $\begin{array}{c}\text { Örneklemde yer alan Arçelik } \\
\text { televizyon reklamlarının kronolojik } \\
\text { gelişiminde; Çelik'in tıpkı bir insan } \\
\text { gibi dünyaya geldiği, büyüyüp } \\
\text { olgunlaştığı, iş sahibi olduğu ve aşık } \\
\text { olup evlendiği görülmektedir. Bu } \\
\text { hayat örgüsü Türkiye toplumunda } \\
\text { erkeklere atfedilen geleneksel rolleri } \\
\text { de yansıtmaktadır: İş hayatına atılmak } \\
\text { ve devamında yuva kurmak. }\end{array}$ & $\begin{array}{l}\text { Çelik düşünen, } \\
\text { sorgulayan, akıl } \\
\text { yürüten, kendi özgür } \\
\text { iradesiyle karar } \\
\text { verebilen bir robot } \\
\text { olarak } \\
\text { resmedilmektedir. }\end{array}$ \\
\hline
\end{tabular}


Marka maskotu Çelik; DiSalvo ve diğerlerinin (2005) geliştirdiği 4 temel antropomorfizm biçimi (yapısal, jest temelli, karakter temelli, farkındalık temelli) çerçevesinde incelendiğinde, robot olduğunu gösteren metal vücut formu dışında tamamen insani özelliklerle donatıldığı görülmektedir.

\section{Merhaba Çelik Reklam Filmi (2002a)}

Çelik'in hayata "merhaba" dediği bu reklam filmi, Arçelik markasının yeni konumlandırmasını tüketiciye duyurma amacını taşımaktadır. Marka maskotu Çelik'in fabrika bekçisi Sırrı karakteri ile ilk karşılaşması, aynı zamanda Çelik'in tüketici ile de ilk kez karşı karşıya gelişini temsil etmektedir. Bu reklamda marka maskotu Çelik'in düşünme, konuşma, iletişim kurma gibi insani yetiler sergilediği görülmektedir (Şekil 1).
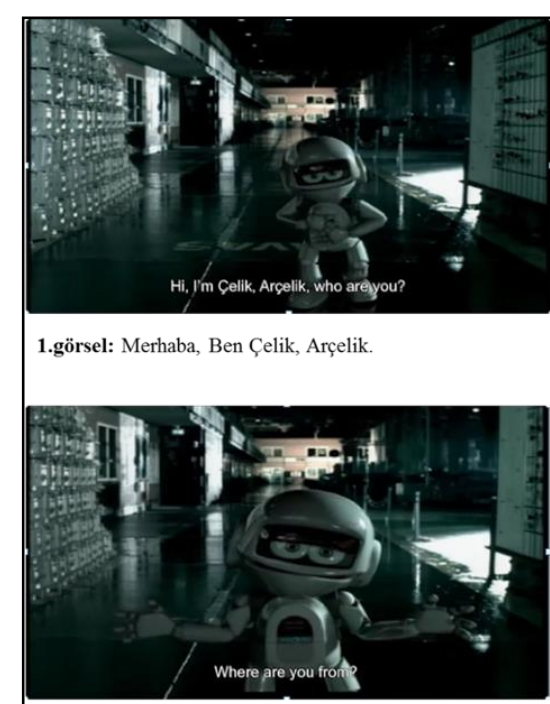

3.görsel: Nerelisin?

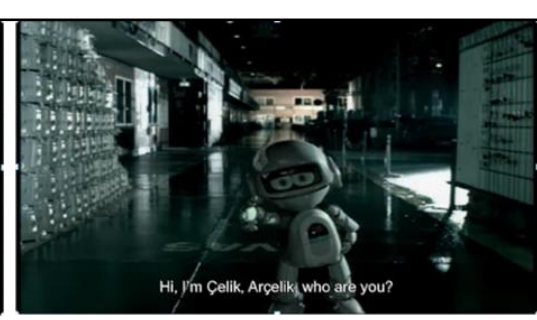

2.görsel: Ya sen kimsin?

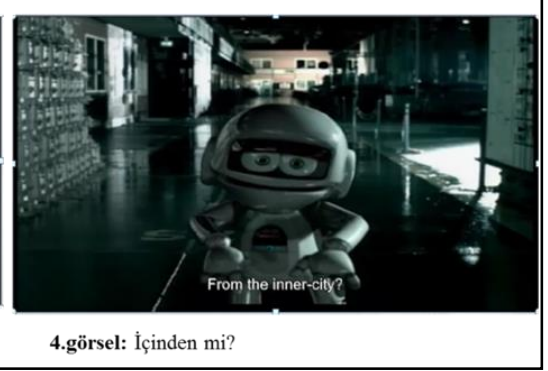

Şekil 1. Antropomorfik Marka Maskotu Celik’in Merbaba Celik Reklammnda Gösterge Olarak Ürettiği Anlamlarn Örnek Kareleri

a) Antropomorfik marka maskotu Çelik'in bir gösterge olarak ürettiği anlamlar: Peirce'nin anlamlandırma modelinde yer alan görüntüsel gösterge, belirtisel gösterge ve sembol kategorileri çerçevesinde incelenen marka maskotu Çelik'in üç farklı anlam ürettiği gözlemlenmiştir (Tablo 2). Görüntüsel gösterge olarak Çelik bir robottur ve bu onun teknolojik olduğunun kanıtıdır. Çünkü robot olmak teknolojinin varlığının belirtisidir. Marka maskotu Çelik sembol olarak incelendiğinde ise Türkiye'de üretilmesi üzerinden yerliliğin sembolü olarak konumlandırıldığ1 görülmektedir. Marka maskotu Çelik aynı zamanda konuşan ve iletişim kuran bir robottur. Bu özellik onun insaniliğine işaret etmektedir. Çelik'in, günlük hayatta insanların birbirleri ile ilk tanışmada sorduğu "nerelisin?" sorusunu karşısındaki Bekçi Sırrı karakterine yöneltmesi, sorunun devamında "içinden mi??" gibi Türkiye kültürüne ait kalıplar kullanması Çelik'in "Türkiyeli", "buralı", "bizden biri” kavramlarını sembolize ettiğini göstermektedir. Son olarak; marka maskotu Çelik’in Bekçi Sırrı ile aralarındaki diyaloğu yönlendirmesi, sorduğu sorulara aldığı cevaplar üzerinden akıl yürütmesi onun düşünen bir robot olduğunun göstergesidir. Bu insani yetiler aynı zamanda Çelik'in akıllı olduğunun da belirtisidir. İnsan gibi düşünen ve davranan bir robot olan Çelik teknolojik zekanın sembolü olarak konumlandırılmaktadır.

Tablo 2. Merhaba Çelik Reklamındaki Antropomorfik Marka Maskotu Celik'in Gösterge Olarak Ürettiüi Anlamlar

\begin{tabular}{cccc}
\hline & Anlam $^{1}$ & Anlam $^{2}$ & Anlam $^{3}$ \\
\hline Görüntüsel Gösterge & Robot & Konuşan robot & Düşünen robot \\
Belirtisel Gösterge & Teknolojik & İnsanilik & Ak1llilık \\
Sembol & Yerli üretim & Bizden biri & Teknolojik zeka \\
\hline
\end{tabular}

b) Antropomorfik marka maskotu Çelik'in Merhaba Çelik reklamı olay örgüsü içerisinde bir gösterge olarak ürettiği düz ve yananlamlar: Reklam hikayesinde marka maskotu Çelik'in yaratıllş anı resmedilmektedir. Çalışan makineler ve üretim bantlarında bir araya getirilen robot parçalarının gösterdiği 
şey buranın bir fabrika olduğudur ve fabrika, üretim ve teknolojinin göstergesidir. Düz anlam düzeyindeki üretim ve teknoloji kavramı yan anlam düzeyine geçildiğinde yeni bir göstergenin göstereni haline gelmektedir. Üretim ve teknolojinin işaret ettiği yananlam ise "robotizasyon"dur. Bu iki kavram bir araya gelerek marka maskotu Çelik göstergesini oluşturmaktadır (Tablo 3).

Tablo 3. Merhaba Celik Reklamindaki Düz ve Yananlamlar

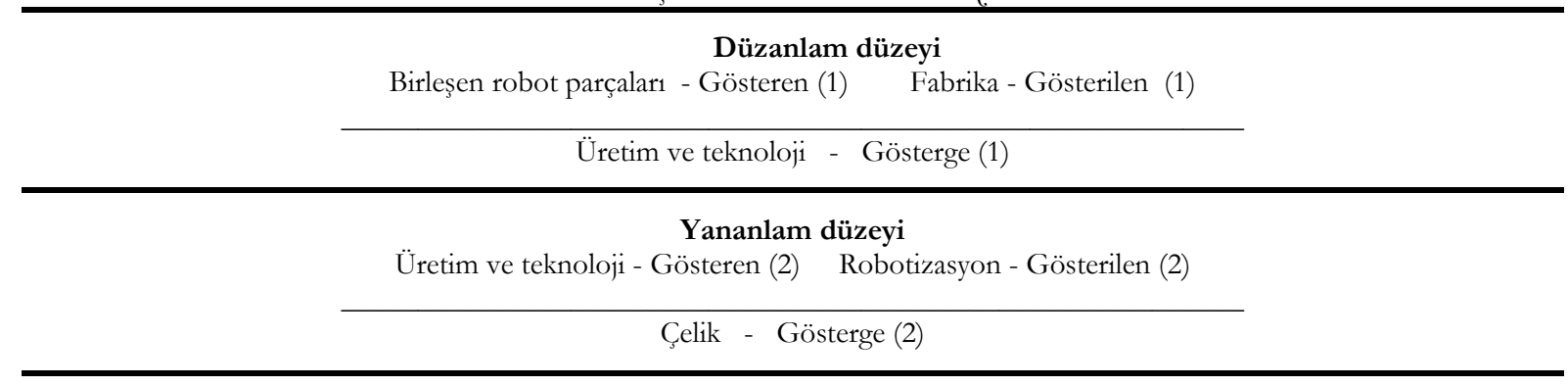

Barthes'in (2018) yananlamın bir diğer boyutu olarak nitelediği mitik anlam boyutunda incelendiğinde ise; marka maskotu Çelik konuşan, diyalog kuran, düşünen, fikir yürüten bir robottur. Bu antropomorfik özellikler ise onu yarı insan yarı robot olduğuna gönderme yapmaktadır. Buradan hareketle, Çelik iki türün kesişiminde yer alan yeni bir türün temsilcisidir. İnsanın zihnine, robotun teknolojisine sahiptir.

Dolayısıyla, ak1llı teknolojinin göstergesidir.

\section{Arçelik Yeni Logo Lansmanı Reklam Filmi (2002b)}

Çelik'in Arçelik markasının marka maskotu olarak tüketiciye tanıtılması sonrasındaki ikinci televizyon reklam filminde markanın yeni logosunun lansmanı yapılmıştır. Reklam hikayesinde antropomorfik marka maskotu Çelik’in Arçelik markasının yeni logosunu tasarladığı görülmektedir. Ona Arçelik çalışanı olduğu anlaşılan bir mühendis ve Bekçi Sırrı eşlik etmektedir. Yeni logonun marka maskotu Çelik’in gövdesinden çıkan bir kâğıt üzerinde yazılı olması; marka kimliğinin temel bileşeni logo ve marka maskotu arasındaki ilişkinin yakınlığını vurgulamaktadır. Her iki marka kimliği unsuru da markanın birer temsilcisi olarak konumlandırılmaktadır. Ayrıca; reklam boyunca Bekçi Sırrı'nın farklı Arçelik ürünleriyle konuşması, ürünlerin Çelik'in ürettiği yeni logoya tepki vermeleri, sadece Çelik'in değil Arçelik markalı ürünlerin de antropomofize edildiğinin bir göstergesidir.

Söz konusu reklamda antropomorfik marka robotu Çelik'in öne çıkan insani yönleri arasında dans etme, şarkı söyleme, diyalog kurma, yaratıcı düşünme ve fikir geliştirme kabiliyeti gibi özellikler yer almaktadır. Ayrıca, reklamın sonunda Arçelik çalışanı mühendisin Çelik’i öpmesi sonrasında robotun utandığı görülmektedir. Bu da Çelik’in naif ve utangaç bir mizacı olduğuna gönderme yapmaktadır (Şekil 2).
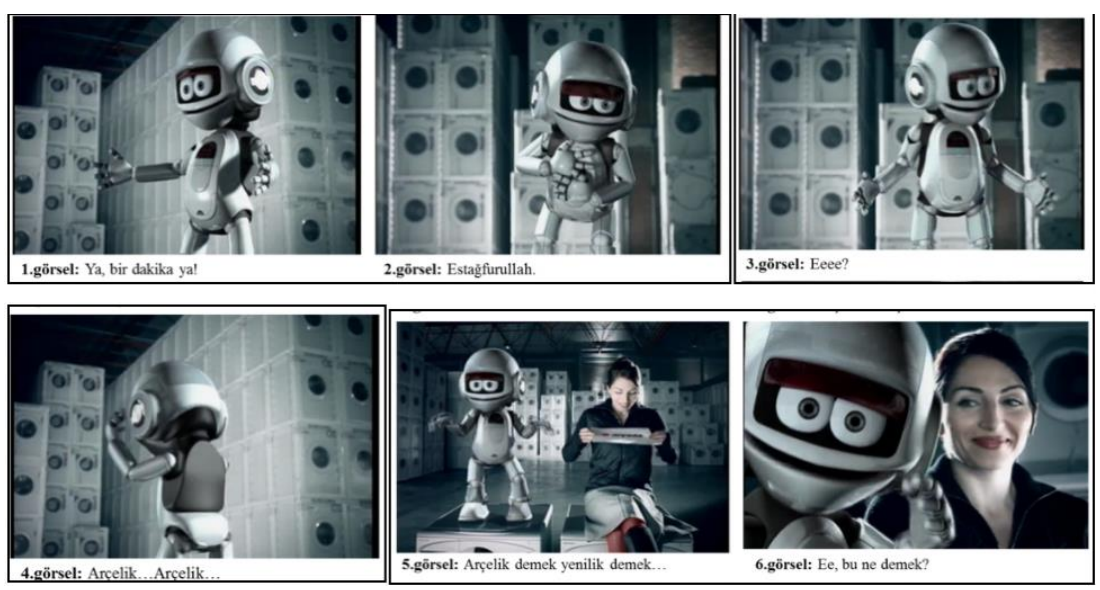

Şekil 2. Antropomorfik Marka Maskotu Celik’in Yeni Logo Lansman Reklamında Gösterge Olarak Ürettiği Anlamlarn Örnek Kareleri 
a) Antropomorfik marka maskotu Çelik'in bir gösterge olarak ürettiği anlamlar: Marka maskotu Çelik görüntüsel gösterge olarak düşünen ve tasarlayan bir robottur. Bu da Çelik'in yaratıcıllı̆ının bir belirtisidir. Arçelik'in yeni logosunu Çelik'in tasarllyor oluşu marka maskotunun inovatif yönünü temsil etmekte ve onu yenilikçiliğin bir sembolü olarak konumlandırmaktadır.

Ayrıca, Çelik konuşurken "Estağfrullah” gibi Türkiye kültürüne ait konuşma kalıpları kullanmaktadır. Bu özelliği Çelik’’n Türkiyeli bir robot olduğunun, onun yerelliğinin bir belirtisidir. Çelik robot vücuduna ve aklına sahip yerel bir figür olarak resmedilmektedir. Bu anlamda da teknolojik gelenekselliği temsil etmektedir. Teknolojinin çoğunlukla yenilikle ve inovasyon ile özdeşleştirildiği düşünüldügünde kavramsal olarak ilerlemeci olduğu söylenebilir ve bu anlamda da geleneksel dışıdır. Dolayısıyla; marka maskotu Çelik "teknolojik geleneksellik" olarak isimlendirilen ve ikili zıtlık olarak nitelenebilecek bu kavramın sembolü haline gelmektedir. Antropomorfizmin temel işlevlerinden birinin bu tür ikili karşıtlıkları aşmak olduğu düşünüldüğg̈nde marka maskotu olarak Çelik'in bu iki zıt kavramın kesişiminde konumlandırıldığ1 düşünülebilir.

Reklam olay örgüsü çerçevesinde; marka maskotu Çelik’in gövdesinden çıkararak yarattı̆̆ı logo diğer Arçelik ürünleri tarafindan beğenildiğinde mutlu olup tıpk1 bir insanmış gibi şark1 söylemekte ve dans etmektedir. $\mathrm{Bu}$ antropomorfik davranışlar Çelik'in eğlenceli bir mizacı olduğuna gönderme yapmaktadır. $\mathrm{Bu}$ anlamda Çelik enerjikliğin ve pozitifliğin sembolü haline dönüşmektedir. Reklam hikayesinin sonunda Arçelik çalışanı yaptı̆̆ logo için Çelik'e teşekkür etmek amacıyla yanağından öptügünde marka maskotu bu davranışı çözümleyememekte, anlamamakta ve utanmaktadır. Bu bağlamda insani bir duygu olan utanmak; antropomorfik marka maskotu Çelik'in çocuksuluğunun ve naifliğinin bir belirtisidir ve karakterin masumiyetini sembolize etmektedir (Tablo 4).

Tablo 4. Arçelik Yeni Logo Lansmanı Reklamındaki Antropomorfik Marka Maskotu Celik'in Gösterge Olarak Ürettigi Anlamlar

\begin{tabular}{|c|c|c|c|c|}
\hline & Anlam $^{1}$ & Anlam $^{2}$ & Anlam $^{3}$ & Anlam $^{4}$ \\
\hline Görüntüsel Gösterge & $\begin{array}{l}\text { Kültürel jestlerle } \\
\text { konuşan robot }\end{array}$ & $\begin{array}{l}\text { Düşünen ve fikir } \\
\text { geliştiren robot }\end{array}$ & $\begin{array}{c}\text { Dans eden ve şark1 } \\
\text { söyleyen robot }\end{array}$ & Utanan robot \\
\hline Belirtisel Gösterge & Türkiyelilik, Yerellik & Yaratıcilik & Eğlenceli & Naiflik, Çocuksuluk \\
\hline Sembol & Teknolojik geleneksellik & Yenilikçilik & Enerjiklik, Pozitiflik & Masumiyet \\
\hline
\end{tabular}

b) Antropomorfik marka maskotu Çelik'in Yeni Logo Lansmanı reklamı olay örgüsü içerisinde bir gösterge olarak ürettiği düz ve yananlamlar: Düzanlam düzeyinde değerlendirildiğinde; Çelik'in gövdesinden çıkan logo gösteren, tasarım süreci gösterilendir. Bu ilişki sonucunda ortaya çıan gösterge Yaratıcı Çelik'tir. Bu çerçevede, düzanlam düzeyinde marka maskotu Çelik'in antropomorfik özelliği olarak yaratıcılık vurgulanmaktadır. Çelik'in temsil ettiği insani özellik "şeyler arasında yeni ilişkiler kurma becerisi" olarak tanımlanabilecek yaratıcı düşünme yetisidir. Reklam hikayesi boyunca; Bekçi Sırrı Çelik'e Arçelik ürünlerinin bir logodan neler beklediklerini iletmektedir. Sempatik, enerjik, dünya markası şeklinde dile getirilen sıfatların aynı zamanda Arçelik markasının kişilik özellikleri olduğu anlaşılmaktadır.

Düzanlam düzeyinin göstergesi Yaratıcı Çelik, yananlam düzeyinde gösteren haline gelmektedir. Gösterilen ise insan düşüncesi ve robot teknolojisinin birleşmesidir. Bu iki unsurun bir araya gelmesiyle Yeni Arçelik göstergesi oluşmaktadır. Bu bağlamda, Arçelik logosunun Çelik'in yaratım sürecinin bir sonucu olarak gösterilmesi, Arçelik markasının antropomorfik marka maskotu Çelik ile özdeşleştirilmesi biçiminde okunabilir (Tablo. 5).

Tablo 5. Arcelik Yeni Logo Reklamindaki Düz ve Yananlamlar

\begin{tabular}{|c|c|c|}
\hline \multicolumn{3}{|c|}{ Düzanlam düzeyi } \\
\hline Çelik'in gövdesinden çıkan log & fo - Gösteren (1) & Tasarım süreci - Gösterilen (1) \\
\hline \multicolumn{3}{|c|}{ Yaratıcı Çelik - Gösterge (1) } \\
\hline \multicolumn{3}{|c|}{$\begin{array}{l}\text { Yananlam düzeyi } \\
\text { İnsan düşüncesi + Robot teknolojisi - Gösterilen (2) }\end{array}$} \\
\hline \multicolumn{3}{|c|}{ Yeni Arçelik - Gösterge (2) } \\
\hline
\end{tabular}


Mitik anlam düzeyine geçildiğinde ise; antropomorfik marka maskotu Çelik'in kimliği ile Arçelik marka kimliğinin örtüştürülmesi, Çelik'in sahip olduğu özelliklerin Arçelik markasına ya da Arçelik'in kişilik özelliklerinin Çelik'e aktarılmasına yol açmaktadır. Bu noktada, Çelik’in yerel deyişlerle konuşması yerelliğini vurgularken aynı zamanda Arçelik'in bir Türkiye markası olmasını temsil etmektedir. Diğer taraftan; reklam hikayesinde Arçelik markası küresel olarak nitelenmektedir. Dolayısıyla, ortaya konan mitik anlam Arçelik markasının "yerel bir küresellik" kavramının da temsilcisi olduğudur. Bu durum, birbiriyle uzlaşmaz olarak görülen ikili karşıtlıkların marka maskotu Çelik’in kişiliğgi üzerinden Arçelik markasına aktarılma stratejisinin takip edildiği şeklinde okunabilir. "Teknolojik geleneksellik" ve "yerel küresellik" şeklindeki ikili karşıtlıklar antropomorfizm üzerinden uzlaştırllabilir anlam kategorilerine dönüştürülmektedir.

\section{Arçelik Divide \& Cool Teknolojisi Reklam Filmi (2008)}

Bu reklam filminde marka maskotu Çelik, İcat Şampiyonları Konferansı'nda açılış konuşması yapmak üzere yurtdışına gitmektedir ve havaalanına doğru yola çıkmışıı. Bu sırada aklına bir fikir geldiğini söyler ve konferansa gitmekten vazgeçer. Bu fikir, soğutma ünitelerini modüler şekilde ayırmayı ve mutfağın farklı yerlerinde kullanmayı mümkün kılan yeni “Arçelik Divide \& Cool Teknolojisi”dir. Antropomorfik marka maskotu Çelik'in reklam boyunca öne çıkan insani özellikleri arasında yabancı dil konuşma yetisi, yaratıcı düşünme, yaratıcı fikri uygulamaya dönüştürme kabiliyeti, bir meslek sahibi olma yer almaktadır. Reklamın merkezindeki tema Çelik’in yaratıcıllğı sayesinde artık globalleştiğidir (Şekil 3).

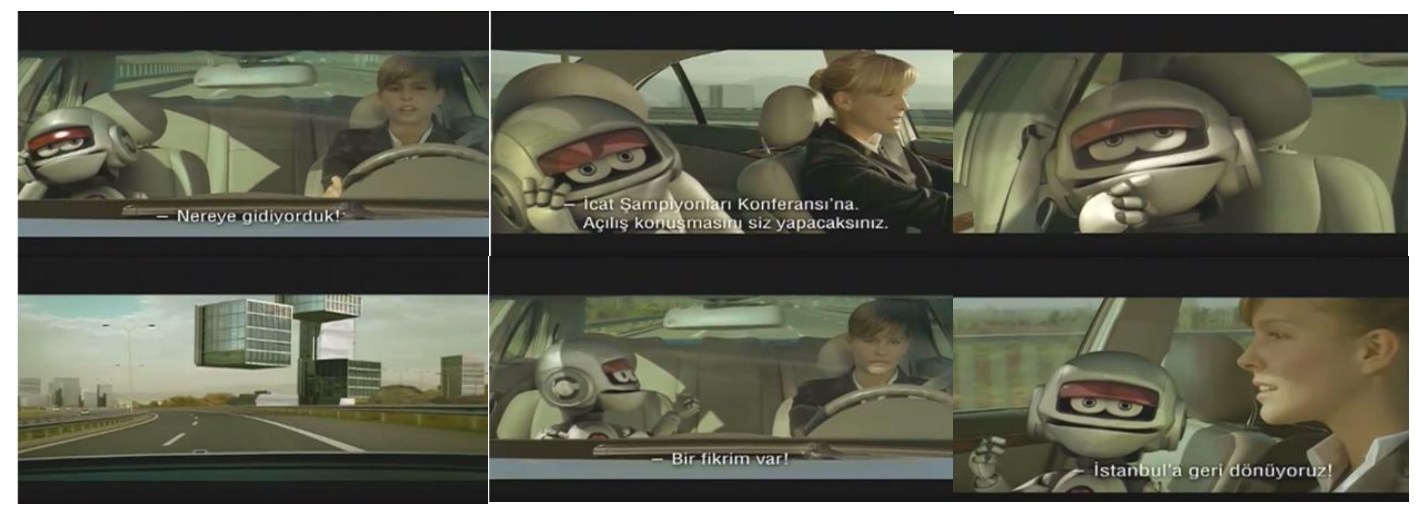
Şekil 3. Antropomorfik. Marka Maskotu Celik'in Divide \& Cool Reklammnda Gösterge Olarak Ürettig̈i
Anlamlarn Örnek Kareleri

a) Antropomorfik marka maskotu Çelik'in bir gösterge olarak ürettiği anlamlar: Reklamda marka maskotu Çelik görüntüsel gösterge olarak düşünen ve fikir üreten bir robot olarak sunulmaktadır. $\mathrm{Bu}$ Çelik'in yaratıcı olduğunun bir belirtisidir. Havaalanı yolunda seyir halindeyken, Çelik binaların modüler bir şekilde parçalara ayrilarak yeni binalar oluşturduğunu görür. Daha sonrasında bunun Çelik'in hayal gücü olduğu anlaşılır. Reklamda, bu hayalin Çelik’in Divide\&Cool Teknolojisi’ne kaynaklık ettiği ima edilmektedir. Dolayısıyla, fikir üreten robot Çelik yaratıcllğı işaret etmekte, bu da inovasyon gücünü sembolize etmektedir. İnovasyon aynı zamanda Arçelik'in marka kimliğinin de sembolü olarak konumlandırılmaktadır. Ayrıca, Çelik'in yabancı dil konuşan bir figür olması onun dünya vatandaşı olduğunun bir belirtisidir. Farklı coğrafyalarla etkileşim halinde olabileceğinin bir işaretidir. Bu Çelik'in Türkiye'nin sınırlarını aşan global kimliğini sembolize etmektedir. Bu globalliği mümkün kılan şey Çelik'in yaratıcı fikirleridir. Son olarak, reklam filminde Çelik, çalışan iş sahibi bir karakter olarak görülmektedir. Bu Çelik'in daha önceki reklamlarda vurgulanmayan bir yönüdür. Çelik'in makam arabasına benzeyen bir taşıt içerisinde ve bir şoför eşliğinde havaalanına gidiyor oluşu onun iş alanında lider bir pozisyonda olmasını sembolize etmektedir (Tablo 6).

Tablo 6. Arçelik Divideぬ Cool Reklamındaki Antropomorfik Marka Maskotu Celik'in Gösterge Olarak Ürettiği Anlamlar

\begin{tabular}{cccc}
\hline & Anlam $^{1}$ & Anlam $^{2}$ & Anlam $^{3}$ \\
\hline Görüntüsel Gösterge & Fikir üreten robot & Yabancı dil konuşan robot & Çalışan robot \\
Belirtisel Gösterge & Yaratıcılık & Dünya vatandaşı & Meslek sahibi \\
Sembol & İnovasyon & Globallik & Liderlik \\
\hline
\end{tabular}


b) Antropomorfik marka maskotu Celik'in Divide\&Cool Teknolojisi reklamı olay örgüsü içerisinde bir gösterge olarak ürettiği düz ve yananlamlar: Düzanlam düzeyinde, Almanya'da İcat Şampiyonası'nda açılış konuşmasına çağırrlmak Çelik'in yaratıcı gücüne işaret etmektedir. Burada Almanya (gösteren), mühendislik ve endüstri (gösterilen) kavramlarına işaret etmektedir. Dolayısıyla; Almanya'da konferansta açılış konuşması yapmak, bu yaratıcıllğın sadece tasarım ile ilgili değil aynı zamanda endüstriyel yönü ağır basan bir yaratıcılık olduğunu göstermektedir. Çelik global bir yaratıcı teknolojinin sembolü olarak konumlandırılmaktadır. Yananlam düzeyine geçildiğinde ise bu Çelik'in alanındaki lider konumuna gönderme olarak değerlendirilebilir. Bu durum, Çelik'in inovasyon gücüyle Türkiye'nin ötesine geçen global bir lider olduğunu ortaya koymaktadır (Tablo 7).

Mitik anlam düzeyinde değerlendirildiğinde; Almanya yolundaki marka maskotu Çelik, Arçelik'in sadece Türkiye'de değil dünya çapında en iyilerle yarışan ve onları geride bırakan bir inovasyon markası olduğunu temsil eden bir figürdür. Çelik tarafından geliştirildiği görülen ve dünyada bir ilk olan "Divide\&Cool Teknolojisi" de bunun bir kanıtıdır.

Tablo 7. Arcelik Divide \& Cool Reklamindaki Düz ve Yananlamlar

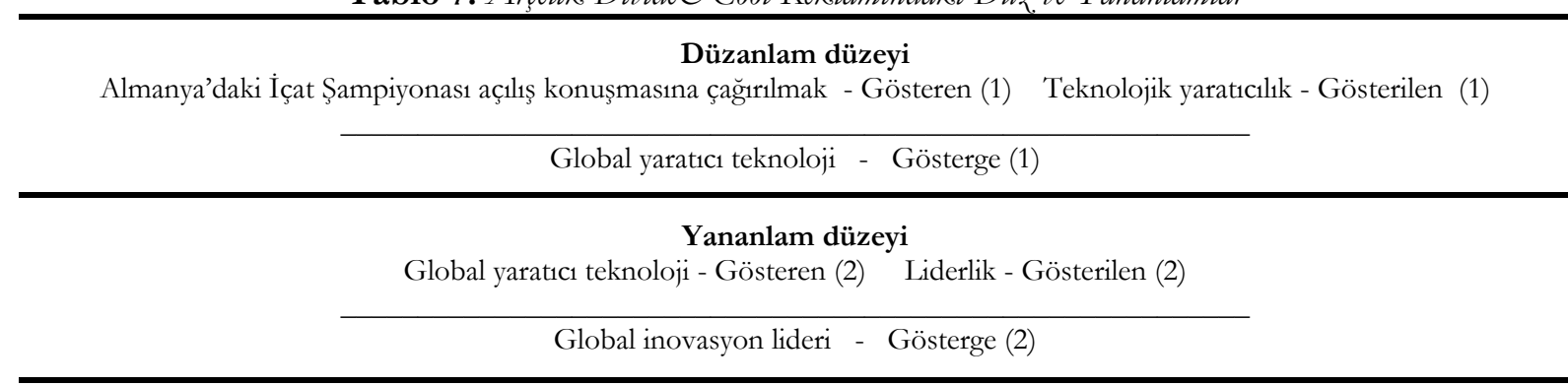

\section{Arçelik Y1lın Düğ̈nü Reklam Filmi (2012)}

"Yılın Düğünü" reklamına baktığımızda, marka hikayesinin odağında Çelik'in Çeliknaz ile evliliği olduğu görülmektedir. Teknolojinin temsilcisi Çelik, tasarımın temsilcisi olarak konumlandırılan Çeliknaz ile hayatını birleştirmektedir. Bu durum, Arçelik'in marka kimliğinin de yeni kişilik özellikleriyle dönüştüğünü göstermektedir. Diğer yandan, antropomorfik marka maskotu Çelik artık yetişkin bir erkek olmuştur ve sevdiği kadın Çeliknaz ile evlenmektedir. Reklam filminde ikisinin düğünü resmedilmektedir. Evli çift ilk danslarını sanatçı Yaşar'ın seslendirdiği klasik düğün şarkısında tango yaparak gerçekleştirirler. Çelik'in aşı olan, evlenen, yeni evlendiği kadınla dans eden, insanlarla kutlama yapan ve dolayısıyla da sosyalleşen bir erkek olduğuna yönelik temsiller marka maskotunun antropomorfik özelliklerinin de ifadesidir (Şekil 4)
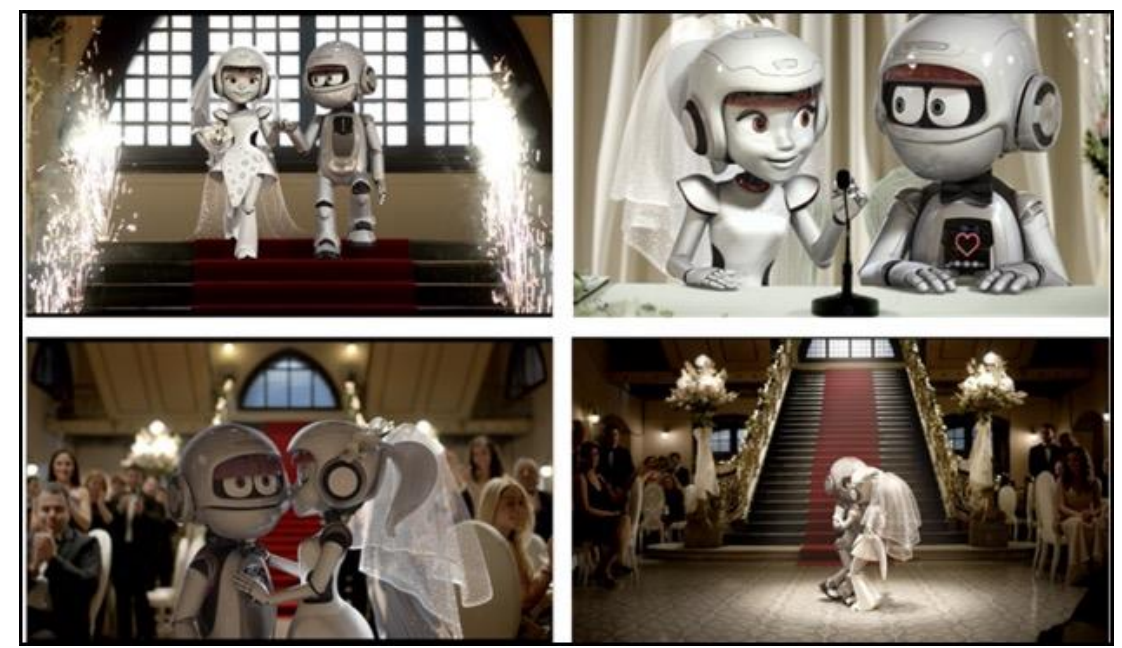

Şekil 4. Antropomorfik Marka Maskotu Çelik’in Yuln Dü̈üüü Reklammnda Gösterge Olarak Ürettiği Anlamlarn Örnek Kareleri 
a) Antropomorfik marka maskotu Çelik'in bir gösterge olarak ürettiği anlamlar: Çelik'in vücudunun ön panelinde tüm reklam boyunca yer alan kalp işareti Çelik'in duyguları olan ve hisseden bir robot olduğunun temsilidir. Çelik'in kadın bir robota âşık olması onun cinsiyet olarak erkek olduğunun belirtisidir. Dolayısıyla Çelik, cinsiyet gibi insana dair özellikler üzerinden antropomorfize edilmektedir. Çelik'in bir cinsiyetinin olması onun aynı zamanda biyolojik bir varlık olduğunu sembolize etmektedir. Bu da Çelik'in antropomorfik bir marka maskotu olarak teknoloji ile biyolojinin kesişiminde konumlandırıldığını göstermektedir. Daha önceki reklamlarda da kullanılan bu ikili karşıtlıkları bir araya getiren kavramların marka maskotunun karakteristik özelliklerini temsil etmesi antropmorfizmin işlerlikte olduğunu göstermektedir. Çelik’in bir insan(biyolojik)/robot(teknolojik) olduğunun altı bir kere daha çizilmektedir (Tablo 8).

Tablo 8. Arçelik Yılın Dügünü Reklamundaki Antropomorfik Marka Maskotu Celik'in Gösterge Olarak Ürettiğgi Anlamlar

\begin{tabular}{cccc}
\hline & Anlam ${ }^{1}$ & Anlam $^{2}$ & Anlam $^{3}$ \\
\hline Görïntüsel Gösterge & Kadın robota aşı olan robot & Evlenen robot & Dügün dansı olarak tango \\
Belirtisel Gösterge & Erkeklik & Bağlllı & Sofistike \\
Sembol & Teknolojik biyoloji & Yetişkinlik & Tutkulu \\
\hline
\end{tabular}

b) Antropomorfik marka maskotu Çelik'in Y1lın Dügünü reklamı olay örgüsü içerisinde bir gösterge olarak ürettiği düz ve yananlamlar: Düz anlam düzeyinde değerlendirildiğinde; evlenen Çelik imgesinin işaret ettiği durum Çelik’in damat oluşudur. Örneklemde yer alan diğer reklamlarda marka maskotu Çelik'in cinsiyeti vurgulanmazken, evlenme eylemi (gösteren) ve damat olmak (gösterilen) Çelik'in cinsiyetinin erkek olduğunun altını çizmektedir. Bu durum Çelik ile Çeliknaz’ın dansında daha da görünür kılınmaktadır. Dans süresince Çelik karakterinin Çeliknaz karakterini yönlendirdiğini, yeri geldiğinde çevik ve kıvrak hareketlerle havaya kaldırdığını görmekteyiz. Çelik'in erkekliği yananlam düzeyinde gücünün gösterenine dönüşmektedir. Bu sadece bir kas gücüne gönderme değildir. Aynı zamanda Çelik’in yapısal gücünü de temsil etmektedir. Dolayısıyla, bu teknolojik bir güçtür. Söz konusu dans sahnesi Çelik'in bir erkek olarak sevdiği kadınla etkileşimine odaklanmaktadır ve güçlü bir aşk1/birleşmeyi temsil etmektedir (Tablo 9).

Tablo 9. Arçelik Yilın Dügünü Reklamındaki Düz ve Yananlamlar

\begin{tabular}{c} 
Düzanlam düzeyi \\
Evlenen robot - Gösteren (1) Damat - Gösterilen (1) \\
\hline Erkek Çelik - Gösterge (1) \\
Erkek Çelik - Gösteren (2) Teknolojik güç - Gösterilen (2) \\
Güçlü aşk/birleşme - Gösterge (2) \\
\hline
\end{tabular}

Mitik anlam düzeyinde incelendiğinde ise, marka maskotu Çelik’in giderek sosyal bir varlığa dönüştüğüne tanıklık etmekteyiz. Marka maskotu Çelik'in robot ve teknolojik bir varlık olmasının getirebileceği soğuk, rasyonellik ve bireysellik gibi olası çağrışımların âşık olmak, evlenmek gibi insana dair duygu ve eylemlerle aşılmaya çalışıldığı okuması yapılabilir. Aynı zamanda, evlenmesi antropomorfik bir maskot olarak Çelik'in artık yetişkinlik dönemine girdiğinin de bir göstergesidir. Tüm bu değerlendirmeler ışı̆̆ında, robot Çelik giderek daha fazla antropomorfize edilmekte ve bu durum Çelik'in robottan insana doğru evriminin bir adım ileriye taşındığına işaret etmektedir.

Bunlara ek olarak, düğün gösteren olarak evliliğe (gösterilen) o da bir birleşmeye (gösterge) işaret etmektedir. Bu birleşme ise teknolojiyi temsil eden marka maskotu Çelik ile tasarım ve zerafeti temsil eden Çeliknaz'n birleşmesidir. Yeni logo lansmanında Çelik'in karakter özelliklerinden biri olarak sunulan yaratıcı düşünce bu reklam filmiyle Çeliknaz'a aktarılmaktadır. Teknolojinin yanı sıra tasarım ve zerafet aynı zamanda Arçelik markasının temel iki değerinin de yansıması olduğu anlaşılmaktadır. Reklamın sonunda dışsesin bunun Arçelik için yeni bir dönemin başlangıcı olduğunu anons etmesi yananlam düzeyinde evliliğin yeni dönemin göstereni olarak konumlandırıldığını anlatmaktadır. Bu da Arçelik’in temel marka değerlerinden yenilik kavramını temsil eden bir durum olarak değerlendirilebilir. 


\section{Marka Maskotu Strateji Modeli Bağlamında Antropomorfik Marka Maskotu Çelik’in Analizi}

Göstergebilimsel analiz yöntemiyle incelenen Arçelik reklamlarında, marka maskotu Çelik'in antropomorfik özellikleri üzerinden inşa edilen anlamların, aslında markanın kimliğine dair özelliklere gönderme niteliğinde olduğu sonucuna varılmıştır. Bu açıdan, Arçelik’in marka kimlik bileşenleri ve marka maskotu Çelik'in antropomorfik özellikleri örtüşmekte ve ortak anlamlar üzerinden işlerlik kazanmaktadır.

Marka maskotu Çelik ve Arçelik markası arasındaki ilişki, Brown'un (2010) maskot strateji modeli çerçevesinde Tablo 10'da incelenmiştir. Brown (2010, s. 218-219) markayla maskotun birbirinin yerine geçer biçimde tekleştiği durumları "eşleştirme"; maskotun ürün veya hizmeti tanıttı̆̆ ancak markayı temsil etmediği durumları "karıştırma"; markalı ürün veya hizmet özelliklerinin birden fazla maskot tarafindan temsil edildiği durumlanı "çoğaltma"; marka ve maskot arasındaki ilişkinin tüketicinin merakını tetikleyecek şekilde örtük bırakıldığı durumları "gizem katma" strateji modeli olarak betimlemektedir. Maskotun marka adı, logosu, mesajı ve ürünler ile yakın ilişkisi göz önünde bulundurularak Çelik’in, söz konusu modeller içinde eşleştirme modelini yansıttığı sonucuna ulaşılmıştır. İncelenen modellerde Çelik'in en uzak olduğu model ise marka ve maskot arasındaki bağlantının kurulamadığ1 gizem katma strateji modelidir. $\mathrm{Bu}$ anlamda, bu analiz sonucunda Çelik'in marka ve marka kimliği ile bağlantısının çok güçlü olduğu yönünde bir sonuç ortaya çıkmaktadır. Ayrıca, Çelik'in yanına eklenen Çeliknaz'ın Arçelik markasının kimliğini tasarım özelliğiyle genişlettiği gözlemlenmektedir. Bu durum, Yılın Dügünü reklam filmiyle birlikte "çoğaltma maskot stratejisi”ne geçiş yapıldığını göstermektedir.

Tablo 10. Brown'un Marka Maskotu Strateji Modeline Göre Antropomorfik Marka Maskotu Celik'in Incelenmesi

\begin{tabular}{|c|c|c|c|}
\hline $\begin{array}{l}\text { Eşleştirme } \\
\text { (Match) }\end{array}$ & $\begin{array}{l}\text { Karıştırma } \\
\text { (Mix) }\end{array}$ & $\begin{array}{l}\text { Çoğaltma } \\
\text { (Multiply) }\end{array}$ & $\begin{array}{c}\text { Gizem Katma } \\
\text { (Mystify) }\end{array}$ \\
\hline $\begin{array}{l}\text { Çelik isminin Arçelik marka } \\
\text { isminin bir parçası olması, } \\
\text { reklam filmlerinde Çelik’in } \\
\text { bazen Arçelik markasının } \\
\text { ürünlerini ifade etmek için, } \\
\text { bazen de tamamen Arçelik } \\
\text { markası yerine kullanılması, } \\
\text { marka ile marka maskotunun } \\
\text { birbirinin yerine geçer } \\
\text { biçimde tekleştiği durumu } \\
\text { yansıtan "eşleştirme" } \\
\text { stratejisinin işlerlikte } \\
\text { olduğunu göstermektedir. }\end{array}$ & $\begin{array}{l}\text { Marka maskotu Çelik, marka } \\
\text { kimliğinin özelliklerini } \\
\text { yansıtmaktadır. } \\
\text { Sadece Arçelik markalı } \\
\text { ürünleri tanıtan bir figür } \\
\text { değildir. Bu sebeple } \\
\text { karıştırma stratejisi } \\
\text { uygulamada değildir. }\end{array}$ & $\begin{array}{c}\text { "Ne kadar fazla marka } \\
\text { karakteri o kadar iyi”" } \\
\text { yaklaşımı olarak da } \\
\text { nitelendirilen "çoğaltma" } \\
\text { stratejisi Arçelik markasının } \\
\text { Çeliknaz robotuyla hayata } \\
\text { geçirdiği maskot stratejisidir. } \\
\text { Çelik’in yanına eklemlenerek } \\
\text { marka kimliğini } \\
\text { güçlendirmiştir. Çelik } \\
\text { teknolojiyi, Çeliknaz ise } \\
\text { tasarımı temsil etmektedir. }\end{array}$ & $\begin{array}{l}\text { Marka maskotu Çelik ve } \\
\text { Arçelik markası arasındaki } \\
\text { bağlantı çok açık ve } \\
\text { görünürdür. } \\
\text { Dolayısıyla, gizem katma } \\
\text { stratejisi mevcut değildir. }\end{array}$ \\
\hline
\end{tabular}

\section{Tartışma, Sonuç ve Öneriler}

Antropomorfizm, cansız varlıklara insani özelliklerin yüklenmesine dayanmaktadır (Guthrie, 1997). Bu özellikler insanı çağrıştıran görünüş ya da insana benzeyen ses tonu gibi fiziksel boyutların yanı sıra davranış, duygu, kişilik gibi soyut unsurları da içermektedir. Antropomorfizm marka maskotlarında kullanıldığı takdirde, marka kişiliğini temsil eden bir figür, diğer bir deyişle marka kimliğinin bir göstergesi haline gelmektedir.

Bu çalışma kapsamında, Arçelik markasının maskotu Çelik'e yüklenen antropomorfik özellikler üzerinden ortaya çıkan marka kimliğine yönelik anlamlar incelenmiştir. Çalışmada ele alınan antropomorfik maskot Çelik'in, Arçelik'in yeniden konumlandırma stratejisi çerçevesinde hayata geçirdiği yeni marka logosunu tanıtan ve marka mesajlarını tüketiciye ileten yüz olması ve markanın insani yönünün Çelik robotuyla temsil edilmesi maskotun amaçlarından biri olan marka kimliğini güçlendirme işlevini başarıla yerine getirdiğini göstermektedir. Buradan hareketle yapılan analiz sonucunda, markanın kimliğinde yaptı̆̆1 tüm değişimleri marka adına duyuran ve bu değişimlerin yaratıcısı olarak kahramanlaştırılan Çelik'in marka kimliği ile bütünleştiği sonucuna ulaşılmıştır. Bu Brown'un (2010) geliştirdiği marka maskot stratejilerinden "eşleştirme" stratejisinin işlerlikte olduğunu göstermektedir. Ayrıca; Arçelik'in 2012 reklamlarında Çelik'in yanı sıra Çeliknaz'ın da marka maskotu olarak sunulması, "ne kadar fazla marka karakteri o kadar iyi" görüşünü yansıtan "çoğaltma" stratejisinin de hayata geçirildiğini vurgulamaktadır

Çelik maskotunun fiziksel açıdan bir robot olmasına rağmen insanvari konuşmaları, insani duyguları ve davranışları sergileme yetisi ve insan gibi fikir yürütme becerisi; onun bir robottan daha fazlası olduğuna 
işaret etmektedir. Çelik'in antropomorfik özellikleri üzerinden yapılan göstergebilimsel analiz sonucunda; Çelik'e atfedilen anlamların aynı zamanda marka kimliğinin de bir parçası olarak da konumlandırıldığı sonucuna ulaşılmıştır. Bulgular, reklamlarda kullanılan belirtisel göstergelerin genellikle Çelik'in kişiliğine göndermede bulunduğunu, toplumsal anlamların temsilcisi olan sembollerin ise Çelik’in hayat görüşüne işaret ettiğini göstermektedir.

Antropomorfizmin ikili karşıtlıkları aşmaya yarayan bir strateji olduğu düşüncesi alan çalışmalarında yer verilen argümanlardan biridir (Rossolatos, 2013, s. 5). Antropomorfizm zıtlıkların birlikte çalışmasını mümkün kılmaktadır. Örneğin, Kellogg’un Frosted Flakes markalı mısır gevreğinin maskotu Tony the Tiger hem insan hem de hayvandır ve manimal (man + animal) olarak adlandırılmaktadır. Çalışma kapsamında incelenen Arçelik reklamlarında, insan ve robot karşıtlığının yoğunlukla kullanıldığı ve Çelik'in bir robot-insan olarak konumlandırıldığı ortaya konmuştur. Bu durum antropomorfizmin ikili karșıtlıkları aşma stratejisi olarak kullanıldı̆̆ savını destekler nitelikte bir bulgudur. Yapılan göstergebilimsel analiz; insan-robot karşıtlığının anlamsal olarak duygu ve mantık, geleneksel ve modern, yerel ve global, gelenek ve teknoloji gibi zitlıklarla desteklendiğini ortaya koymuştur.

Markanın global kimliğine Çelik'in konuşma tarzı üzerinden atfedilen yerellik, markanın teknolojik kimliğine Çelik'in hissetme yetisi üzerinden atfedilen duygusallık; marka kimliğinin de bu zıtlıkların yarattı̆̆1 anlamlarla tanımlanmasını sağlamaktadır. Çelik bir gösterge olarak değerlendirildiğinde ortaya çıan "teknolojik geleneksellik", "teknolojik zeka", "rasyonel duygu”, "teknolojik güç” benzeri anlamlar Arçelik'in bir teknoloji markası olmasına işaret ederken, Çelik'e atfedilen liderlik, yaratıcıllk, dost canlısı, enerjik gibi özellikler marka kimliğinin insani yönünü vurgulamaktadır. Çelik, Arçelik markasıyla tamamen bağdaşan bir maskot olduğu için (eşleştirme modeli), bu anlamların da markanın Çelik yoluyla tüketicisine aktarmaya çalıştığı insani yönleri olduğu sonucuna ulaşılmıştır.

Çelik maskotunun reklamları üzerinde yapılan göstergebilimsel analiz sonucunda ortaya çıkarılan antropomorfik anlamlar ile Arçelik marka kimliği arasındaki bağlantı Tablo 11'de gösterilmiştir. $\mathrm{Bu}$ çerçevede, insani teknoloji, global yerli inovasyon, teknolojik yenilikçilik ve teknolojik uyumluluk gibi özelliklerin Arçelik marka kimliğinin temsilcileri olarak tanımlandığı görülmektedir.

Tablo 11. Celik'in Antropomorfik Özellikleri Üzerinden Arçelik Marka Kimlig̈ine Yönelik Yaratulan Anlamlar

\begin{tabular}{|c|c|c|}
\hline $\begin{array}{c}\text { Çelik'in sahip olduğu antropomorfik } \\
\text { özellikler }\end{array}$ & $\begin{array}{l}\text { Antropomorfik özelliklerin işaret } \\
\text { ettiği yananlamlar üzerinden inşa } \\
\text { edilen zıtlıklar }\end{array}$ & $\begin{array}{c}\text { Çelik'in antropomorfik özelliklerinin } \\
\text { marka kimliğinde işaret ettiği } \\
\text { anlamlar }\end{array}$ \\
\hline Yaratıc1 & Robot/İnsan & $\begin{array}{c}\text { Insani Teknoloji } \\
\text { İnsanın düşüncesi ve teknolojinin gücü. }\end{array}$ \\
\hline Ak1lli & Rasyonel/Duygu & $\begin{array}{c}\text { Global Yerli Inovasyon/Teknolojik } \\
\text { Yenilikcilik }\end{array}$ \\
\hline Türkiyeli & Globallik/Yerellik & $\begin{array}{l}\text { Türkiye'nin sınırlarını aşan rekabetçilik } \\
\text { ve ürün geliştirmede yenilikçilik. }\end{array}$ \\
\hline Tutkulu & Aşk/Mantık & Teknolojik Uyum \\
\hline Erkek & Teknoloji/Biyoloji & Teknoloji ve tasarımın birleşimi. \\
\hline
\end{tabular}

Sonuç olarak, pazarlamanın merkezine tüketicinin konulmasıyla birlikte markalar da tüketiciler için birer yaşam partneri olarak değerlendirilmeye başlamıştır (Fournier, 1998). Bu bağlamda; rakiplerinden farklılaşmak isteyen markaların tüketicilerin dünyasında geçerliliği olan belirli anlamları ve onların özdeşlik kurabilecekleri kişilik özelliklerini sahiplenmesi şaşırtıcı değildir. Bu anlam ve özelliklerin marka maskotları aracılı̆̆yla sunulması da maskotların antropomorfize edilmesine ivme kazandırmıştır. $\mathrm{Bu}$ ivme, önümüzdeki dönem araştırmalarında maskotların marka kimliğinin birer göstergesi olarak ele alınmasına yönelik incelemeleri de hızlandıracaktır. Hali hazırdaki çalışma, Arçelik marka kimliğinin marka maskotu olarak Çelik'in antropomorfik özellikleriyle tamamen örtüşen biçimde nasıl başarıyla inşa edildiğini ortaya koymuştur. Bu noktada, Çelik'in tüm özellikleriyle Arçelik marka kimliğinin bir göstergesine dönüştüğü bulgulanmıştır.

Çalışmanın sonuçları, markaların maskotlarına atfettikleri insani özellikler noktasında dikkatli davranmaları gerektiğini göstermektedir. Çünkü, maskot marka kimliğinden bağımsız değerlendirilmemelidir. Dolayısıyla, pazarlamacılar maskotun taşıdığı tüm özelliklerin marka için birer 
kimlik unsuru haline dönüşeceğini hesaba katmalıdır. Ayrıca, marka kimliğini güçlendirmede maskot tek başına yeterli değildir. Marka temsilcisi olarak değerlendirilen ve marka kimliğinin göstergelerinden biri olan maskotların; taşıdıkları insani özellikler ve bu özelliklerin içerdiği anlamlar bağlamında diğer marka bileşenleri ile uyum içerisinde olması gerekmektedir. Bu uyum marka kimliğinin de daha sağlam olmasını sağlayacaktır.

İnsanların kendisi dışındaki her türlü varlı̆̆ı insan gibi algılama eğilimi göz önünde bulundurulduğunda, marka ne kadar insanileşirse o kadar etkili olacağ1 varsayılabilir. Bu bağlamda pazarlamacılar; maskotları sadece insani özelliklerle donatmanın da ötesine geçerek onları ihtiyaçları, arzuları ve beklentileri olan figürler haline getirmelidir. Böylece, marka maskotları insanileşme yönünde bir adım ileriye taşınabilir.

\section{Etik Beyan}

"Marka Maskotlarnda Antropomorfizm Kullanımına Yönelik Göstergebilimsel Bir Analiz: Arçelik Markası Robot Çelik Vakası" başlıklı çalışmanın yazım sürecinde bilimsel, etik ve alıntı kurallarına uyulmuş; toplanan veriler üzerinde herhangi bir tahrifat yapılmamış ve bu çalışma herhangi başka bir akademik yayın ortamına değerlendirme için gönderilmemiştir.

\section{Kaynakça}

Aaker, D. (2016). Güllü markalar yaratmak (3. Bask1). İstanbul: MediaCat.

Akerson, F. E. (2016). Göstergebilime giriş (1. Baskı). İstanbul: Bilge Kültür Sanat.

Aggarwal, P. ve McGill, A. L. (2012). When brands seem human, do humans act like brands? Automatic behavioral priming effects of brand anthropomorphism. Journal of Consumer Research, 39(2), 307-323.

Asquith, P. (1984). The Inevitability and utility of anthropomorphism in description of primate behaviour. Ed. R. Harré ve V. Reynolds, The meaning of primate signals (s.138-174). Cambridge: Cambridge University Press.

Barthes, R. (2018). Cağdas söylenler (5. Bask1). İstanbul: Metis.

Barutçu, S. ve Adıgüzel, D. Ü. (2015). Sevimli pazarlama ve maskotların marka farkındalığı marka bağlılığı ve markaya yönelik tutum üzerindeki etkisi: Karş1laştırmalı bir araştırma. Ekonomi ve Yönetim Araștırmalar Dergisi, 4(2), 76-93.

Beirao, A. C., Lencastre, P. ve Dionisio, P. (2007). Children and brand mascots. 6th International Marketing Trends Congress.

Erişim: http:// citeseerx.ist.psu.edu/viewdoc/download;jsessionid=4BBEDEC259C8B86E496E6A49F09F1C45?doi= 10.1.1.585.2099\&rep=rep1\&type $=$ pdf

Belk, R. W. (1988). Possessions and the extended self. Journal of Consumer Research, 15(2), 139-168.

Bignell, J. (2002). Media semiotics: An introduction. Manchester: Manchester University Press.

Blackston, M. (1993). Beyond brand personality: Building brand relationships. Ed. D. A. Aaker, ve A. L. Biel, Brand Equity and Advertising (s. 113-124). Hillsdale, New Jersey: Lawrence Erlbaum.

Brown, S. (2010). Where the wild brands are: Some thoughts on anthropomorphic marketing. The Marketing Review, 10(3), 209-224.

Brown, S. (2011). It's alive inside! A note on the prevalence of personification. Irish Marketing Review, 21(1-2), 3-11.

Brown, S. (2014). Mascot mania: Monkeys, meerkats, martians and more. Ed. E. Brown ve S. Ponsonby-McCabe, Brand Mascots and Other Marketing Animals (s.1-16). London, New York: Routledge.

Böke, K. (2011). Örnekleme. Ed. K. Böke, Sosyal Bilimlerde Araştırma Yöntemleri (3. Baskı). İstanbul: Alfa.

Castelli, F., Happe, F., Frith, U. ve Frith, C. (2000). Movement and mind: A functional imaging study of perception and interpretation of complex intentional movement patterns. Neuroimage, 12(3), 314-325.

Caufield, K. (2012) Analyzing the effects of brand mascots on social media: Johnson City Power Board case study (Yayınlanmamış Yüksek Lisans Tezi). East Tennessee State University, Tennessee.

Chandler, D. (2002). Semiotics: The basics. Oxon: Routledge.

Chandler, J. ve Schwarz, N. (2010). Use does not wear ragged the fabric of friendship: Thinking of objects as alive makes people less willing to replace them. Journal of Consumer Psychology, 20, 138-145.

Çengel, K. T. (2006). Marka yönetiminde hedef tüketicilerin maskot kullanulan markah ürünlere yönelik algisı üzerine etki eden faktörlerin belirlenmesi ve temizlik ürünleri sektöründe bir uygulama (Yüksek Lisans Tezi). İstanbul Üniversitesi, Sosyal Bilimler Enstitüsü, İstanbul.

Danesi, M. (2004). Messages, signs, and meanings (3. Baska). Toronto: Canadian Scholars’ Press.

Daston, L. ve Mitman, G. (2005). Thinking with animals: New perspectives on anthropomorphism, New York: Columbia University Press.

DiSalvo, C., Gemperle, F. ve Forlizzi, J. (2005). Imitating the buman form: Four kinds of anthropomorphic form. Erişim: http://www.cs.cmu.edu/ kiesler/anthropomorphism-org/pdf/Imitating.pdf

Donaldson, T. J. (2016). Brand love and the ideal self: The function of anthropomorphism in brand love. Almanya, Moldova: Lap Lambert Academic Publishing. 
Dydynski, J. M. (2017). Perception of cuteness in animal mascots/characters (Yüksek Lisans Tezi). University of Tartu, Tartu.

Epley, N., Waytz, A. ve Cacioppo, J. T. (2007). On seeing human: A three-factor theory of anthropomorphism. Psychological Review, 114(4), 864-886.

Epley, N. ve Waytz, A. (2010). Mind perception. Ed. S. T. Fiske, D.T. Gilbert ve G. Lindzey, The Handbook of Social Psychology (s.498-541). Hoboken, NJ: Wiley.

Fiske, J. (2013). İetişim çalısmalarna giriş (3. Baskı). Ankara: Pharmakon.

Fournier, S. (1998). Consumers and their brands: Developing relationship theory in consumer research. Journal of Consumer Research, 24(4), 343-373.

Fournier, S. ve Alvarez, C. (2012). Brands as relationship partners: Warmth, competence, and in-between. Journal of Consumer Psychology, 22(2), 177-185.

Guthrie, S. E. (1993). Faces in the clouds: A new theory of religion. New York, Oxford: Oxford University Press.

Guthrie, S. E. (1997). Anthropomorphism: A definition and a theory. Ed. R. W. Mitchell, N. S. Thompson ve H. L. Miles, Anthropomorphism, Anecdotes, and Animals (s.50-58). Albany, NY: Satate University of New York Press.

Gülver, N. (2017). Marka ve maskot arasındaki çatışma seviyesinin maskotun beğenilme ve hatırlanmasına, yer aldığ1 reklama ve ait olduğu markaya karşı tutuma olan etkileri (Yüksek Lisans Tezi). İstanbul Bilgi Üniversitesi, Sosyal Bilimler Enstitüsü, İstanbul.

Heckman, J. (1999). Care and feeding of mascots. Marketing News, 33(6), 1.

Hofstede, G. (2011). Dimensionalizing cultures: The Hofstede model in context. Online Readings in Psychology and Culture, 2(1), 1-26. Erişim: https://scholarworks.gvsu.edu/cgi/viewcontent.cgi?article=1014\&context=orpc

Hume, D. (1875). The natural history of religion. Ed. T. H. Green ve T. H. Grose, The Philosophical Works of David Hume (s. 309-363). London: Longmans, Green, and Co.

Karadağ, H. E. (2013). Pazarlama iletişim arac olarak maskot kullanımınn marka imajı ve marka farkındalŭg yaratmadaki rolü (Yüksek Lisans Tezi). Celal Bayar Üniversitesi, Sosyal Bilimler Enstitüsü, Manisa.

Kassarjian, H. H. (1978). Presidential adress, 1977: Anthropomorphism and parsimony. Ed. H. K. Hunt, Advances in Consumer Research Vol. 5 (s.xii-xiv). Ann Arbor: Association for Consumer Research.

Khogeer, Y. K. (2013). Brand anthropomorphism: The literary lives of marketing mascots (Doktora Tezi). University of Liverpool, Management School, Liverpool.

Kiesler, T. (2006). Anthropomorphism and consumer behavior. Ed. C. Pechmann ve L. Price, Advances in Consumer Research Vol. 33 (s.149-149). Duluth, MN: Association for Consumer Research.

Kim, H. C. ve Kramer, T. (2015). Do materialists prefer "brand-as-servant"? The interactive effect of anthropomorphized brand roles and materialism on consumer responses. Journal of Consumer Research, 42(2), 284-299.

Kim, S. ve McGill, A. L. (2011). Gaming with Mr. slot or gaming the slot machine? Power, anthropomorphism, and risk perception. Journal of Consumer Research, 38, 94-107.

Küçükerdoğan, R. (2012). Markaların maskot kullanımı ve tüketiciyle etkileşimleri. Brandage, 38, 86-92.

Lakoff, G. ve Johnson, M. (2008). Metaphors we live by. Chicago: University of Chicago Press.

Lencastre, P. ve Côrte-Real, A. (2013). Brand response analysis: A Peircean semiotic approach. Social Semiotics, 23(4), 489-506.

Levy, S. J. (1985). Dreams, fairy tales, animals, and cars. Psychology and Marketing, 2(2), 67-81.

Lin, R., Lin, P. C. ve Ko, K. J. (1999). A study of cognitive human factors in mascot design. International Journal of Industrial Ergonomics, 23(1-2), 107-122.

MacInnis, D. J. ve Folkes, V. S. (2017). Humanizing brands: When brands seem to be like me, part of me, and in a relationship with me. Journal of Consumer Psychology, 27(3), 355-374.

Mohanty, S. S. (2014). Growing importance of mascot and their impact on brand awareness - A study of young adults in Bhubaneswar City. International Journal of Computational Engineering and Management, 17(6), 42-44.

Oswald, L. R. (2015). The structural semiotics paradigm for marketing research: Theory, methodology and case analysis. Semiotica. 205, 115-148.

Özdemir, A. (2010). Yönetim bilimlerinde ileri arastırma yöntemleri ve uygulamalar (2. Bask1). İstanbul: Beta.

Pairoa, I. ve Arunrangsiwed, P. (2016). The effect of brand mascots on consumers' purchasing behaviors. International Journal of Economics and Management Engineering, 10(5), 1702-1705.

Phillips, B. ve Lee, W. (2005). Interactive animation: Exploring spokes-characters on the internet. Journal of Current Issues and Research in Advertising, 27(1), 1-17.

Plummer, J. (2000). How personality makes a difference. Journal of Advertising Research, 40(6), 79-83.

Portal, S., Abratt, R. ve Bendixen, M. (2018). Building a human brand: Brand anthropomorphism unravelled. Business Horizons, 61, 367-374.

Puzakova, M., Kwak, H. ve Rocereto, J. (2009). Pushing the envelope of brand and personality: Antecedents and moderators of anthropomorphized brands. Ed. A. L. McGill ve S. Shavitt, Advances in Consumer Research Vol. 36 (s. 412-420). Duluth, MN: Association for Consumer Research.

Rossolatos, G. (2013). Repressenting the manimal: A semiotic/psychoanalytic approach to the strategic importance of anthropomorphism in branding. 12th International Marketing Trends Conference. France: Paris. 
Rossolatos, G. (2017). Brand image re-revisited: A semiotic note on brand iconicity and brand symbols. Social Semiotics, 28(3), 412-428.

Schiffman, L. G. ve Kanuk, L. L. (2009). Consumer behavior (10. Bask1). New Jersey: Prentice Hall.

Spada, E. C. (1997). Amorphism, mechanomorphism, and anthropomorphism. Ed. R. W. Mitchell, N. S. Thompson ve H. L. Miles, Anthropomorphism, anecdotes and animals (s. 37-49). Albany, NY: State University of New York Press.

Tosun, N. B. ve Kalyoncu, Z. Ö. (2014). Marka farkındalığında maskot kullanımının etkisi. Journal of Life Economics. 1(2), 87-114.

Waytz, A., Epley, N. ve Cacioppo, J. T. (2010). Social cognition unbound: Insights into anthropomorphism and dehumanization. Current Directions in Psychological Science. 19(1), 58-62.

Weszka, P. (2011). Fifa World Cup brand elements and local inspirations. Sports Marketing Quarterly, 20(3), 174-184.

Yadav, P., Bisoyi, D. ve Chakrabati, D. (2015). Anthropomorphic brand mascot serve as the vehicle: To quickly remind customers who you are and what you stand for in Indian cultural context. International Conference on Communication, Visual Arts and Design. Fransa: Paris.

Zakia, R. D. ve Nadin, M. (1987). Semiotics, advertising and marketing. Journal of Consumer Marketing, 4(2), 5-12.

\section{EXTENDED ABSTRACT}

In today's marketing, the idea that brands gain value not just through their benefit but the identity they project and their relationship with consumers is of great importance. In parallel, Fournier (1998: 344) claims that brands are no longer "passive object of marketing exchange, but an active, contributing members of the brand-consumer relationship". This acceptance of brands as relationship partners had precipitated the relocation of brands from the land of the nonmaterial into a world where they are depicted as "animated, humanized or somehow personalized" (ibid.). Past research shows that consumers can easily assign personality traits to brands (Aaker, 2017). Anthropomorphism is the name given to "the tendency of people to make attributions of human like characteristics to animals and nonhuman entities" (Kiesler, 2006: 149). Most of the time, marketers encourage anthropomorphizing by creating brand characters and mascots who mimic the human form, emotions and at times its ability to think and speculate.

The objective of this study is to examine the use of anthropomorphism in brand mascots through Arçelik's Çelik the Robot case, to analyze the meanings that are conveyed by the anthropomorphic qualities of Çelik the Robot and their association with Arçelik's brand identity from a semiotic perspective. The study entails the findings pertaining to three main research questions: (1) Through which semiotic relations the use of anthropomorphism in mascots constructs the meanings associated with brand identity? (2) What denotational and connotational meanings are constructed by way of brand mascot Çelik's anthropomorphic qualities? (3) What kind of meanings are constructed by way of brand mascot Çelik's anthropomorphic qualities regarding Arçelik's brand identity?

Within the confines of this study, four Arçelik television commercials that represent different life stages of Çelik the Robot (childhood-young adulthood-maturity) were selected by purposive sampling method and were subjected to semiotic analysis. The analysis was conducted in three phases. In the first phase, brand mascot Çelik's anthropomorphic qualities were examined by Zakia and Nadin's (1987) Interpretant Matrix which is based on Peirce's iconic, indexic and symbolic sign categorizations. Second phase involves the investigation of Barthes' (2018) denotational and connotational meanings associated with the anthropomorphic brand mascot Çelik. Lastly, the relationship between brand mascot Çelik's anthropomorphic qualities and Arçelik brand identity was analyzed by using Brown's (2010) Mascot Strategy Model (i.e. matching, mixing, multiplying, mystifying).

The findings reveal that human like features that the brand mascot Çelik possessed (e.g. smart, creative, world citizen) match with the main determinants of Arçelik's renewed brand identity (e.g. technological, innovativeness, global locality). This shows that during Arçelik brand's repositioning campaign "the match strategy" was in place. This strategy is characterized by congruence, whereby the brand name, the logo, the mascot (i.e. Çelik) and the product/service (i.e. Arçelik) are essentially one and the same. Moreover, the introduction of Çeliknaz the Robot as Çelik's love affair demonstrates that "multiply mascot strategy" that epitomizes "the more the better marketing approach" was also implemented. 
In addition, the semiotic analysis shows that the meanings associated with brand mascot Çelik's anthropomorphic qualities also reflects Arçelik's brand identity. Within this perspective, humanly technology, global locality, technologic innovativeness and design driven technology are communicated as the main qualities of the renewed Arçelik's brand identity. These qualities are constructed through Çelik's anthropomorphic traits (i.e. creative, smart, Turkish, passionate, man) and over symbolic binary oppositions of robot vs. human, ration vs. emotion, global vs. local, love vs. logic, technology vs. biology. These findings imply that brand mascot Çelik with all the human qualities infused to him also supports Arçelik's new brand positioning.

The results of the study have several managerial implications. Brand managers should be careful when anthropomorphizing their brand mascots because of the interdependency between the brand and the mascot. They should take into account that all the anthropomorphic traits of the brand mascot will eventually become one of the constituents of the brand identity. Therefore, when creating or using a brand mascot one has to ensure that there is a complete correspondence between mascot's personality traits and other elements of the brand identity. This consistency will maintain the strength of the brand identity.

Considering people's universal inclination to make attributions of humanlike characteristics to things around themselves, "the more human the better" motto can be a wise strategy to pursue in terms of branding. In this respect, marketers should go beyond humanizing their mascots by way of humanlike physical features but transform them into figures who have needs, wants and expectations. This approach can help to advance the existence of the anthropomorphic creations in the marketplace and improve their emotional accessibility for the consumers. 